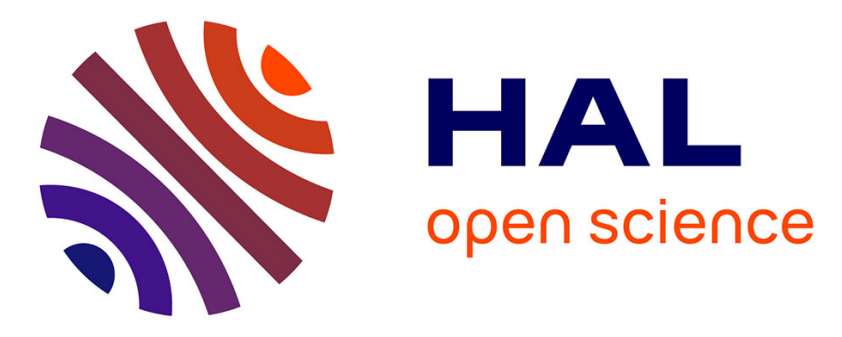

\title{
2-(Substituted amino)-8-azachromones from 4,6-Diaryl-2-pyridones: A Synthetic Strategy toward Compounds of Broad Structural Diversity
}

Steve Saulnier, Rayane Ghoteimi, Christophe Mathé, Suzanne Peyrottes, Jean-Pierre Uttaro

\section{To cite this version:}

Steve Saulnier, Rayane Ghoteimi, Christophe Mathé, Suzanne Peyrottes, Jean-Pierre Uttaro. 2(Substituted amino)-8-azachromones from 4,6-Diaryl-2-pyridones: A Synthetic Strategy toward Compounds of Broad Structural Diversity. Journal of Organic Chemistry, 2020, 85 (18), pp.11778-11793. 10.1021/acs.joc.0c01561 . hal-03007536

\section{HAL Id: hal-03007536 https://hal.science/hal-03007536}

Submitted on 18 Nov 2020

HAL is a multi-disciplinary open access archive for the deposit and dissemination of scientific research documents, whether they are published or not. The documents may come from teaching and research institutions in France or abroad, or from public or private research centers.
L'archive ouverte pluridisciplinaire HAL, est destinée au dépôt et à la diffusion de documents scientifiques de niveau recherche, publiés ou non, émanant des établissements d'enseignement et de recherche français ou étrangers, des laboratoires publics ou privés. 


\title{
2-(Substituted amino)-8-azachromones from 4,6-Diaryl-2-pyridones: a Synthetic Strategy toward Compounds of Broad Structural Diversity
}

Steve Saulnier, Rayane Ghoteimi, Christophe Mathé, Suzanne Peyrottes and Jean-Pierre Uttaro*

Nucleosides \& Phosphorylated Effectors Team, Institut des Biomolécules Max Mousseron, UMR 5247 CNRS, Université de Montpellier, Campus Triolet, cc1705, Place Eugène Bataillon, 34095 Montpellier, France.

\begin{abstract}
3-Acetoacetyl-4,6-diaryl-2-pyridones are synthesized in three steps from chalcones and then condense with carbon disulfide to afford 8-azachromones containing a methylthio group at $\mathrm{C} 2$. This leaving group offers an entry point for the insertion of more complex moieties via nucleophilic substitution. For this purpose, N-nucleophiles are explored according to their positions in the Mayr's nucleophilicity scale $(N$ parameter), and three main classes are distinguished depending on whether the substitution takes place from their neutral forms, from their deprotonated anionic forms, or under nucleophilic catalysis. A broad range of primary and secondary amines may be inserted by this method, including enantiomerically pure amino acids, enabling us to explore structural diversity.
\end{abstract}

\section{TABLE OF CONTENTS GRAPHIC}

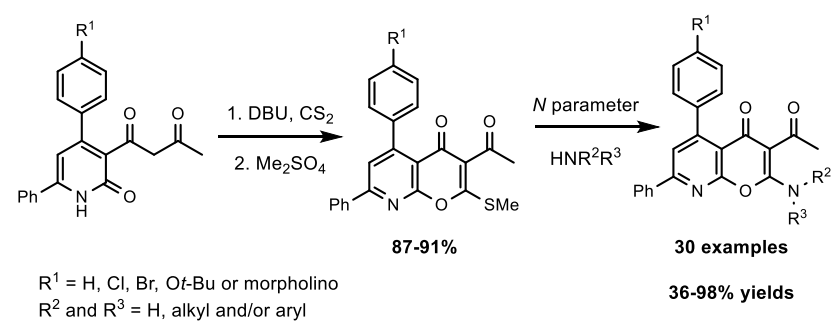




\section{INTRODUCTION}

The 8-azachromone core was synthesized for the first time in 1967 from 1,3-diketone derivatives of 2-pyridones by an acid-catalyzed ring closure. ${ }^{1}$ Since then, few methods have been developed in comparison with the isostere chromones, ${ }^{2}$ although both scaffolds might have similar biological and pharmaceutical properties. ${ }^{3}$ The electron-deficient nature of the pyridine ring is often pointed out as an issue to the challenging access to 8-azachromones. To date, most of the reported procedures still involve 1,3-diketones and fall into two approaches according to whether the ring closure takes place via intramolecular O-arylation or via condensation with carbon disulfide (Scheme 1). The intramolecular O-arylation has been the most explored and can be performed under acid catalysis for 2-pyridones ${ }^{1,4}$ and 2-methoxypyridines, ${ }^{5}$ under base catalysis for 2-halopyridines, ${ }^{6}$ and via $\mathrm{CH}$ activation of $\mathrm{N}$-oxides for 2 -unsubstituted pyridine derivatives ${ }^{7}$ (Scheme 1A). By contrast, the condensation with $\mathrm{CS}_{2}$ was reported solely in the case of 4,6-dimethyl-2pyridone derivatives (Scheme 1B) ${ }^{8}$ and has not received further attention. Yet, the methylthio leaving group at the electrophilic site $\mathrm{C} 2$ on the cyclization product II would enable to access more complex derivatives III by simple nucleophilic substitution. Such derivatization would be more difficult from the O-arylation products $\mathbf{I}$.

\section{Scheme 1. Synthesis of 8-Azachromones from 1,3-Diketone Precursors.}

A. Intramolecular O-arylations (ref. 1, 4-7)

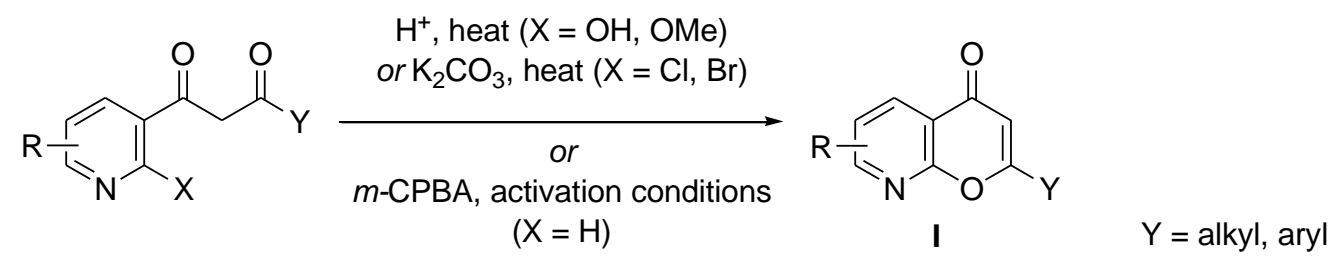

B. Condensation with carbon disulfide and nucleophilic substitution ( $R=$ methyl, ref. $8 ; R=$ aryl, this work)
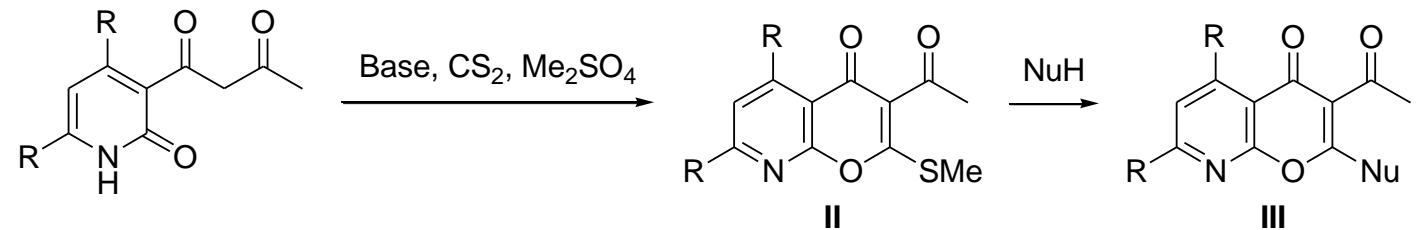

The present work revisits the condensation with $\mathrm{CS}_{2}$ and further explores possibilities of nucleophilic substitution at C2 (Scheme 1B). We focus on 5,7-diaryl-8-azachromone derivatives because aryl substituents on the pyridine ring have not yet been considered by the synthetic methods mentioned above. We show that primary and secondary amines are well suited for the nucleophilic substitution and that they give rise to 2(substituted amino)-8-azachromones under conditions that mainly depend on the nucleophile strength and position in the Mayr's nucleophilicity scale. ${ }^{9}$ The synthesis of the 1,3-diketone cyclization precursors, namely 3-acetoacetyl-4,6-diaryl-2-pyridones, is also described, as they are not easily accessible. 


\section{RESULTS AND DISCUSSION}

Synthesis of 3-Acetoacetyl-4,6-diaryl-2-pyridones. The 1,3-diketones cyclization precursors are commonly prepared by addition of a methyl Grignard reagent to the nitrile of 3-cyano-2-pyridones, followed by Claisen condensation of the resulting 3-acetyl-2-pyridones. This approach has been well described in the case of 4,5-dialkyl-2-pyridones but turned out to be more difficult with 4,5-diaryl derivatives.

Among the numerous methods for the synthesis of the starting material, 4,5-diaryl-3-cyano-2pyridones $\mathbf{1}$, we focused on the base-promoted condensation between chalcones and cyanoacetamide (Table 1). An effective reported procedure involves potassium $t$-butoxide in DMSO under oxygen atmosphere. ${ }^{10}$ When conducted in open air, this procedure leads to a substantial amount of 3-unsubstituted 2-pyridones as by-products of decyanative aromatization, instead of the desired 3-cyano-2-pyridones. ${ }^{11}$ This point is responsible for the modest yield of product 1a (40\%) obtained in open air (Table 1, entry 1), whereas an $88 \%$ yield was reported when using an oxygen atmosphere (data from ref. 10). As other procedures using ethanol as solvent with different bases, and without the need for oxygen atmosphere were reported, ${ }^{12}$ we evaluated the effect of replacing DMSO with ethanol, 2-propanol, and $t$-butyl alcohol, together with the corresponding potassium alkoxide bases in open air (entries 2-5). Under these conditions, we did not observe the decyanative aromatization by-product. The reaction rate clearly depends on the base strength: although the reaction in ethanol/KOEt was still incomplete after 72 hours at room temperature (entries 2 and 3), a 96\% yield of 1a was obtained after 60 hours in 2-propanol/KOi-Pr (entry 4) and 92\% after only 24 hours using the more basic $t$-butyl alcohol/KOt-Bu medium (entry 5). The desired product $1 \mathrm{a}$ is initially formed as potassium salt, and is soluble neither in 2-propanol nor in $t$-butyl alcohol under this form. We took advantage of this insolubility to isolate and characterize 1a as potassium salt $\mathbf{1 a - K}$ in a simplified reaction work-up. According to the same procedure, we prepared 3-cyano-2-pyridones $\mathbf{1 b}$-e-K diversely substituted in the para position of the 4-phenyl ring (Table 1, entries 6-9). 
Table 1. Synthesis of 3-Cyano-2-pyridones from 4-Substituted Chalcones and Cyanoacetamide.

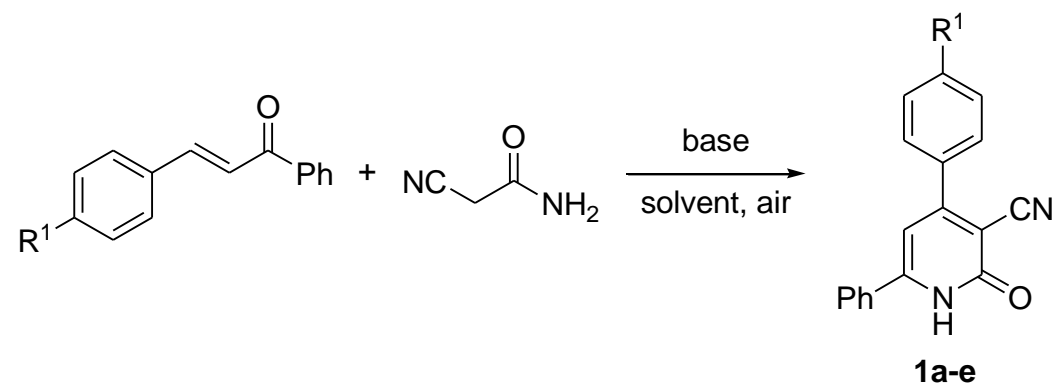

\begin{tabular}{|c|c|c|c|c|c|c|c|}
\hline Entry $^{a}$ & $R^{l}$ & Solvent & Base & Temperature & Reaction time, $h$ & Product $^{b}$ & Yield, $\%^{c}$ \\
\hline 1 & $\mathrm{H}$ & DMSO & $\mathrm{KO} t-\mathrm{Bu}$ & $\mathrm{rt}$ & 2 & $1 \mathbf{a}$ & 40 \\
\hline 2 & $\mathrm{H}$ & ethanol & KOEt & $\mathrm{rt}$ & 20 & $1 a-K$ & 37 \\
\hline 3 & $\mathrm{H}$ & ethanol & KOEt & $\mathrm{rt}$ & 72 & $1 a-K$ & 88 \\
\hline 4 & $\mathrm{H}$ & 2-propanol & $\mathrm{KO} i-\mathrm{Pr}$ & $\mathrm{rt}$ & 60 & $1 a-K$ & 96 \\
\hline 5 & $\mathrm{H}$ & $t$-butyl alcohol & $\mathrm{KO} t-\mathrm{Bu}$ & $30{ }^{\circ} \mathrm{C}$ & 24 & $1 a-K$ & 92 \\
\hline 6 & $\mathrm{Cl}$ & 2-propanol & $\mathrm{KO} i-\mathrm{Pr}$ & $\mathrm{rt}$ & 60 & $1 b-K$ & 93 \\
\hline 7 & $\mathrm{Br}$ & 2-propanol & $\mathrm{KO} i-\mathrm{Pr}$ & $\mathrm{rt}$ & 60 & 1c-K & 96 \\
\hline 8 & $\mathrm{O} t-\mathrm{Bu}$ & 2-propanol & $\mathrm{KO} i-\mathrm{Pr}$ & $\mathrm{rt}$ & 60 & 1d-K & 77 \\
\hline 9 & Morpholino & $t$-butyl alcohol & $\mathrm{KO} t-\mathrm{Bu}$ & $30^{\circ} \mathrm{C}$ & 48 & $1 e-K$ & 93 \\
\hline
\end{tabular}

${ }^{a}$ Reaction conditions: $0.083 \mathrm{M}$ chalcone, 1.1 equiv cyanoacetamide, 4 equiv base, open air. ${ }^{b} \mathbf{1 a - e - K}$ refers to the potassium salts of products 1a-e. ${ }^{c}$ Yields of isolated products.

We assigned the position of the substituted phenyl ring on the basis of the probable reaction mechanism: the Michael addition of cyanoacetamide to the 4-substituted chalcone leads to a condensation product where the substituted phenyl ring would be adjacent to the 3-cyano group, i.e. at $\mathrm{C} 4$. This was later confirmed on the 3-acetyl derivative $2 \mathbf{c}$ by the NOESY correlation between the acetyl group and the ortho protons of the bromo-substituted phenyl ring (Figure 1).

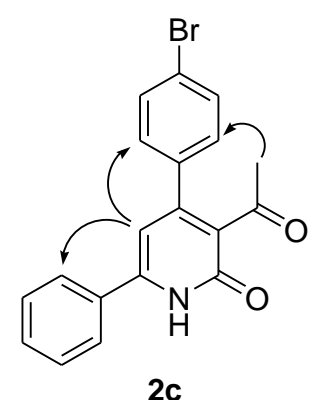

Figure 1. Selected NOESY Correlations (Arrows) Showing the Position of the Substituted Phenyl Ring. 
3-Acetyl-2-pyridones 2 might be obtained directly from chalcones by using acetoacetamide instead of cyanoacetamide in the procedure described above. However, the reaction requires heating under reflux and mainly gives the 3-unsubstituted products resulting from deacetylative aromatization. Therefore, the addition of a methyl Grignard reagent to 3-cyano-2-pyridones appears to be the most reliable strategy to access acetyl derivatives.

Alkyl-substituted cyanopyridones are known to give addition products with methylmagnesium bromide at room temperature. ${ }^{13}$ For aryl-substituted derivatives 1a-e-K, the use of a large excess of $\mathrm{MeMgBr}$ and heating $\left(65{ }^{\circ} \mathrm{C}\right)$ were required to reach a significant conversion. However, under these conditions, halogenated derivatives $\mathbf{1 b}\left(\mathrm{R}^{1}=\mathrm{Cl}\right)$ and $\mathbf{1 c}\left(\mathrm{R}^{1}=\mathrm{Br}\right)$ gave rise to unidentified by-products due to a possible halogen-magnesium exchange. We obtained better results with the more reactive dimethylmagnesium generated in situ by the dioxane precipitation method: addition of 1,4-dioxane to $\mathrm{MeMgBr}$ precipitates $\mathrm{MgBr}_{2}$ species as polymeric dioxane adducts and shifts the Schlenk equilibrium toward $\mathrm{Me}_{2} \mathrm{Mg} .{ }^{14}$ Thus, 3-cyano-2-pyridones 1a-e-K were converted to the corresponding 3-acetyl-2pyridones 2a-e at room temperature with $56-75 \%$ yields after hydrolysis of the imine intermediate products (Scheme 2). The hydrolysis does not need strong acidic conditions and can be performed at $\mathrm{pH}$ around 7-8, enabling to work with the acid-sensitive $t$-butyl ether derivative $\mathbf{2 d}$.

Scheme 2. Two-Step Synthesis of 1,3-Diketones 3 from 3-Cyano-2-pyridones 1-K.
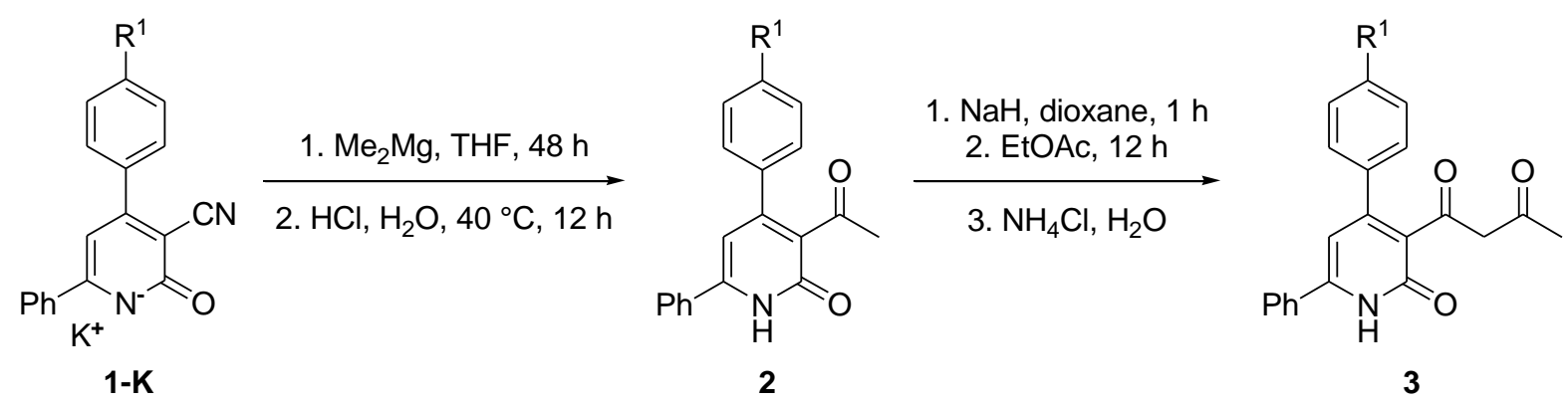

$$
\begin{aligned}
& \text { 1a-K, 2a, 3a }: R^{1}=H \\
& \text { 1b-K, 2b, 3b }: R^{1}=C l \\
& \text { 1c-K, 2c, 3c }: R^{1}=B r \\
& \text { 1d-K, 2d, 3d }: R^{1}=O t \text {-Bu } \\
& \text { 1e-K, 2e, 3e }: R^{1}=\text { Morpholino }
\end{aligned}
$$

2a, $75 \%$

2b, $68 \%$

2c, $65 \%$

2d, $56 \%$

2e, $61 \%$ 3a, $84 \%$

3b, $79 \%$

3c, $72 \%$

3d, $83 \%$

3e, $75 \%$

Finally, the Claisen condensation between 2a-e and ethyl acetate in dioxane led to the 1,3-diketone derivatives 3a-e with yields of $72-84 \%$ (Scheme 2). These compounds were then considered as starting materials for their cyclization into 8-azachromones.

Cyclization into 2-(Methylthio)-8-azachromones. The reported procedure uses potassium hydroxide (two equivalents) as base to promote the condensation with $\mathrm{CS}_{2}$ (three equivalents) in DMSO, followed by treatment with dimethyl sulfate (four equivalents). ${ }^{8,15}$ Under these conditions, diketone 3a gave rise to a mixture of the 2-(methylthio)-8-azachromone $4 \mathbf{a}$ (34\%) and of the 2-methyl derivative 5a (35\%) as intramolecular O-arylation by-product (Scheme 3). As discussed in the introduction, the O-arylation ring 
closure of 2-pyridones has been mainly reported through dehydration under acidic conditions, and 5a is indeed the main product observed (89\%) after a one hour treatment of 3a in sulfuric acid (Scheme 3).

\section{Scheme 3. Cyclization of Diketone 3a into 8-Azachromones According to Reported Procedures.}

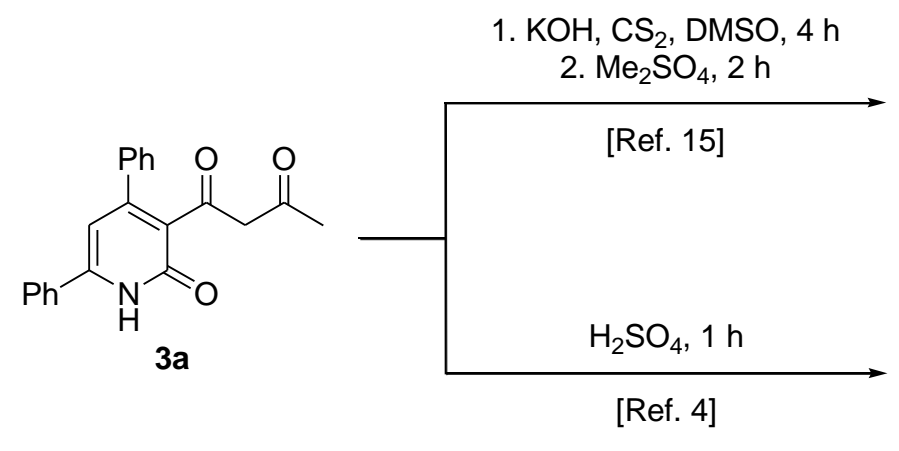

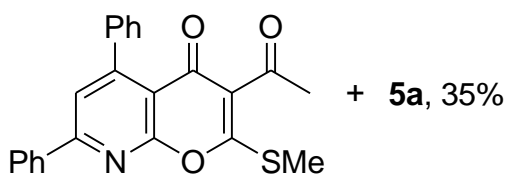

$4 a, 34 \%$

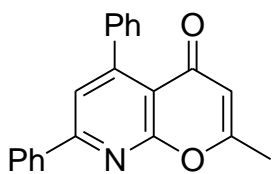

5 a, $89 \%$

With the aim of maximizing the formation of $\mathbf{4 a}$, the reaction conditions, including solvent nature, base strength, equivalents of the reagents, and reaction time were screened and revealed the following points. Firstly, the reaction requires polar solvents such as DMF, DMSO or acetonitrile. As solvent nucleophilicity may be problematic, anhydrous acetonitrile appears to be the solvent of choice, furthermore leading to the selective precipitation of product $\mathbf{4 a}$ in the reaction mixture. Secondly, the use of two equivalents of a base at least as strong as $\mathrm{K}_{3} \mathrm{PO}_{4}$ is required. In this respect, DBU increases the solubility of the deprotonated anionic species in acetonitrile, resulting in higher reaction rates. The third point concerns the amount of $\mathrm{CS}_{2}$. Although one equivalent would theoretically be enough for the reaction to proceed, we observed a decrease in the formation of the O-arylation by-product 5a when using higher amounts of $\mathrm{CS}_{2}$ (up to nine equivalents), thus resulting in a significant increase in the yield of $\mathbf{4 a}$. On the basis of these observations, we developed an improved procedure affording the 2-(methylthio)-8-azachromone derivatives 4a-e with average yields of $87-91 \%$ (Scheme 4). 

azachromones 4 .

(Conditions: $0.1 \mathrm{M} \mathrm{3,} 2.2$ equiv DBU, 9 equiv $\mathrm{CS}_{2}, 2.2$ equiv $\mathrm{Me}_{2} \mathrm{SO}_{4}, \mathrm{rt}$ )

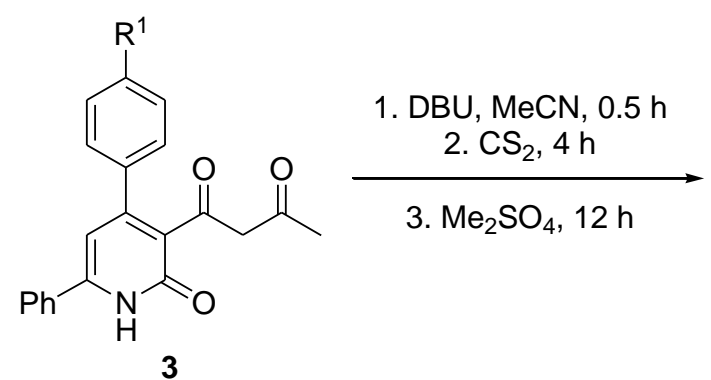

3a, $4 a: R^{1}=H$

$3 b, 4 b: R^{1}=C l$

3c, $4 \mathrm{c}: \mathrm{R}^{1}=\mathrm{Br}$

3d, $4 \mathbf{d}: \mathrm{R}^{1}=\mathrm{O} t-\mathrm{Bu}$

3e, $4 \mathbf{e}: \mathrm{R}^{1}=$ Morpholino<smiles>CC(=O)c1c(C)oc2nc(-c3ccccc3)cc(-c3ccc([Tl])cc3)c2c1=O</smiles>

4

To explain the formation of both cyclization products $\mathbf{4}$ and $\mathbf{5}$, we propose a mechanism in Scheme 5 . This mechanism works on the assumption that dianionic species would not be formed under the conditions of Scheme 3 (KOH, DMSO) or Scheme 4 (DBU, acetonitrile). Deprotonation of diketone 3 gives rise to the multident nucleophilic species $\mathbf{A}$ and $\mathbf{B}$ in equilibrium. They may react with $\mathbf{C S}_{2}$ through the oxygen atom of the pyridone ring or through the enolate, leading to species $\mathbf{C}$ and $\mathbf{D}$, respectively (among other possible reactive sites and intermediate species). The reaction via the enolate carbon atom may be considered as thermodynamically favored, so that the whole equilibrium is shifted toward $\mathbf{D}$, which would then lead to product 4 through two possible paths depending on whether the ring closure takes place via a 6-exo-trig (path A) or a 6-endo-trig reaction (path B). In path B, the thioenolate of $\mathbf{H}$ is first alkylated by either $\mathrm{Me}_{2} \mathrm{SO}_{4}$ or $\mathrm{CS}_{2}$, the latter explaining the need for an excess of $\mathrm{CS}_{2}$. Product $\mathbf{5}$, however, would be formed from species $\mathbf{C}$ after methylation of the dithiocarbonate group, giving $\mathbf{K}$ and the corresponding anionic species $\mathbf{L}$. The leaving group $S$-methyl dithiocarbonate at $\mathrm{C} 2$ enables the intramolecular O-arylation that leads to 5. Actually, this mechanism might involve more complex intermediate species as the above assumption about the absence of dianionic species may not be valid. 
Scheme 5. Plausible Reaction Mechanism for the Formation of Products 4 and 5.

(Counter ions and reversibility of reaction steps are not shown)<smiles></smiles>

A<smiles></smiles><smiles>CC(=O)CC(=O)c1c(Br)cc(-c2ccccc2)nc1OC(=S)[S-]</smiles>

C<smiles>O=C([TeH])CC(=O)c1c(Br)cc(-c2ccccc2)[nH]c1=O</smiles>

3<smiles>CC(=O)/C=C(\[O-])c1c(Br)cc(-c2ccccc2)[nH]c1=O</smiles>

B<smiles></smiles><smiles>CC(=O)C(C(=O)c1c(Br)cc(-c2ccccc2)[nH]c1=O)C(=S)[S-]</smiles>

D<smiles>CC(=O)C(C(C)=O)C(=O)c1c(Br)cc(-c2ccccc2)[nH]c1=O</smiles>

E

Path $A$<smiles>CC(=O)C1C(=O)c2c(Br)cc(-c3ccccc3)nc2OC1(C)S</smiles>

$\mathbf{F}$<smiles>CC(=O)C1C(=O)c2c(Br)cc(-c3ccccc3)nc2OC1(C)S</smiles>

G base $=\mathrm{DBU}$ or $\mathrm{KOH}$ $\mathrm{Z}=\mathrm{Me}$ or $\mathrm{CS}_{2} \mathrm{Me}$ Path $B \quad$ base<smiles>CC(=O)C(C(=O)c1c(Br)cc(-c2ccccc2)[nH]c1=O)=C(C)C</smiles>

H<smiles>[Z]S/C(SC)=C(/C(C)=O)C(=O)c1c(Br)cc(-c2ccccc2)[nH]c1=O</smiles>

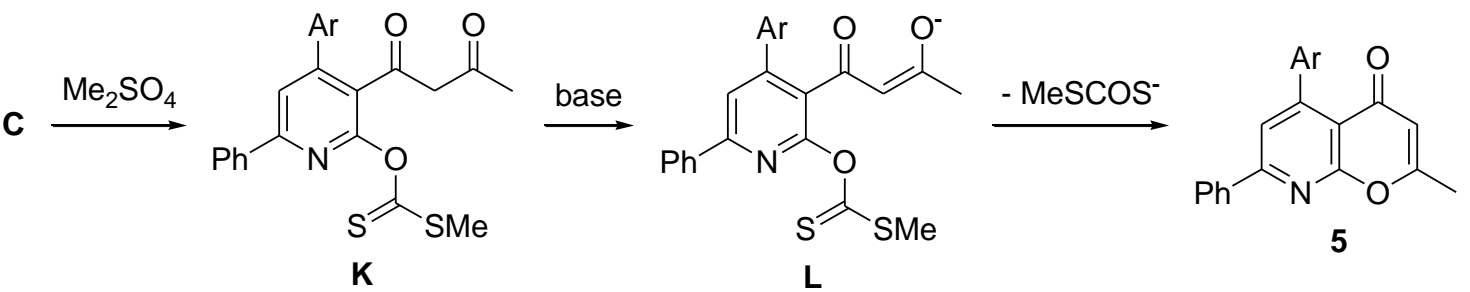

Nucleophilic Substitution of the Methylthio Group. Our approach to exploring the scope of the nucleophilic substitution is based on the Mayr's reactivity scales. These scales are constructed according to the equation $\log k=\mathrm{s}(N+E)$, where the second-order rate constant $k$ of a nucleophile-electrophile combination correlates with the nucleophilicity and electrophilicity parameters $N$ and $E$ of the reagents. ${ }^{9}$ Values of $N$ and $E$ parameters of many reagents have been determined, ${ }^{16}$ so that these scales allow predicting the feasibility of a wide variety of combinations. A given electrophile such as $\mathbf{4 a}$ that reacts with a nucleophile referenced in the nucleophilicity scale (i.e. with a known $N$ parameter), will be expected to react with other nucleophiles of similar or higher $N$ parameters as well. Among the different $\pi-, \mathrm{n}-$ and $\sigma$ nucleophiles characterized in the Mayr's scales, we focused on neutral NH-type nucleophiles because they cover a wide range of nucleophilicity: basically, from $N 7.69$ for benzotriazole to $N 18.52$ for pyrrolidine 
(data in acetonitrile, which was chosen as reference solvent for this work). This means roughly eleven units. In comparison, alcohols cover only six units and are significantly less nucleophilic.

Therefore, we explored the reactivity of $\mathbf{4 a}$ with some N-nucleophiles, starting from piperidine $(N$ 17.35) and decreasing in nucleophilicity (Table 2). We observed the nucleophilic substitution in methylene chloride at room temperature until ethanolamine ( $N$ 14.11, entry 5) and glycine methyl ester ( $N 13.51$ for potassium glycinate, data in water, entry 6). Under the same conditions, $p$-anisidine ( $N$ 13.42) only led to traces of the substitution product $6 \mathbf{a g}$, and weaker nucleophiles such as aniline ( $N$ 12.64) and benzocaine did not react at all, even upon heating at $65^{\circ} \mathrm{C}$ in THF. Thus, a first limit in reactivity is reached for $N$ value of approximately 13.5. Nucleophiles located above this limit give substitution products with 4a whereas nucleophiles below do not, at least without further activation conditions.

To extend the scope of reactivity, we envisaged activation via nucleophilic catalysis. Because they show $N$ parameter values above the limit of 13.5, DBU ( $N$ 15.29), DMAP $(N 15.51)$ and DABCO $(N 18.80)$ were expected to react with $4 \mathbf{a}$ and to give rise to the corresponding positively charged intermediates of enhanced electrophile strengths. Indeed, all three catalysts enabled the nucleophilic substitution with $p$ anisidine and aniline, DMAP being the most effective with 90-91\% yields of 6ag and 6ah after only two hours at $65{ }^{\circ} \mathrm{C}$ in THF (Table 2, entries 7 and 8). However, the efficacy of nucleophilic catalysis is quite limited as benzocaine required 36 hours at $100{ }^{\circ} \mathrm{C}$ in dioxane to afford $61 \%$ of the substitution product 6ai (entry 9), and 2-methylimidazole $(N 11.74)$ and imidazole $(N 11.47)$ were completely unreactive under the same conditions (entries 10 and 11). Therefore, a second limit is reached for $N$ value of about 12, above which the presence of DMAP enables the nucleophilic substitution. 
Table 2. Nucleophilic Substitution of 4a with N-Nucleophiles Depending on the Nucleophilicity

Parameter $N$.

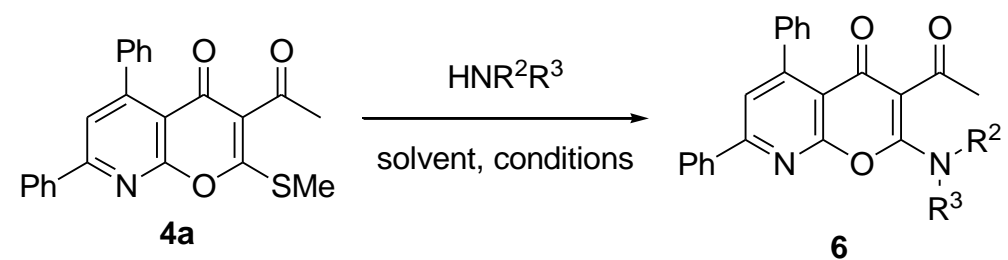

\begin{tabular}{|c|c|c|c|c|c|c|c|c|}
\hline Entry ${ }^{a}$ & $H N R^{2} R^{3}$ & $\begin{array}{c}N \\
\text { parameter }^{b}\end{array}$ & Catalyst & Solvent & Temperature & $\begin{array}{c}\text { Time, } \\
h\end{array}$ & Product & $\begin{array}{l}\text { Yield, } \\
\%^{c}\end{array}$ \\
\hline 1 & & 17.35 & none & DCM & $\mathrm{rt}$ & 12 & 6aa & 96 \\
\hline 2 & $\mathrm{H}$ & 15.65 & none & DCM & $\mathrm{rt}$ & 12 & 6ab & 93 \\
\hline 3 & $\mathrm{MeNH}_{2}$ & 15.19 & none & DCM & $\mathrm{rt}$ & 12 & 6ac & 97 \\
\hline 4 & $\mathrm{H}_{2} \mathrm{~N}$ & 14.29 & none & DCM & $\mathrm{rt}$ & 12 & 6ad & 94 \\
\hline 5 & $\mathrm{H}_{2} \mathrm{~N}^{-}$ & 14.11 & none & DCM & $\mathrm{rt}$ & 12 & $6 \mathbf{a e}$ & 65 \\
\hline $6^{d}$ & $\mathrm{H}_{2} \mathrm{~N} \widehat{\mathrm{CO}_{2} \mathrm{Me}}$ & $13.51^{e}$ & none & DCM & $\mathrm{rt}$ & 12 & 6af & 63 \\
\hline $7^{f}$ & OMe & 13.42 & DMAP & THF & $65^{\circ} \mathrm{C}$ & 2 & 6ag & 91 \\
\hline $8^{f}$ & & 12.64 & DMAP & THF & $65^{\circ} \mathrm{C}$ & 2 & 6ah & 90 \\
\hline $9^{f}$ & $\mathrm{CO}_{2} \mathrm{Et}$ & $\mathrm{n} / \mathrm{a}^{g}$ & DMAP & dioxane & $100{ }^{\circ} \mathrm{C}$ & 36 & 6ai & 61 \\
\hline $10^{f}$ & & 11.74 & DMAP & dioxane & $100^{\circ} \mathrm{C}$ & 12 & & 0 \\
\hline $11^{f}$ & & 11.47 & DMAP & dioxane & $100^{\circ} \mathrm{C}$ & 12 & & 0 \\
\hline
\end{tabular}

\footnotetext{
${ }^{a}$ Reaction conditions: $0.1 \mathrm{M} 4 \mathbf{4 a}$ and 1.1 equiv Nu. ${ }^{b} N$ parameters are given in acetonitrile, data from ref. $16 .{ }^{c}$ Yields of isolated products. ${ }^{d}$ Glycine methyl ester was generated from the corresponding hydrochloride (1.5 equiv) and $\mathrm{Et}_{3} \mathrm{~N}$ (1.1 equiv). ${ }^{e} N$ parameter of the free carboxylate, data in water. ${ }^{f} 0.05 \mathrm{M} \mathrm{4a} .{ }^{g}$ Data not yet available.
}

It is important to note that the products presented in Table 2 were obtained with one equivalent of nucleophile. With an excess, a second substitution takes place and leads to the 2-pyridone derivatives 7 by ring opening, due to the leaving group ability of the pyridone moiety. This second substitution works best 
with cyclic secondary amines and becomes more difficult when the nucleophile strength decreases. In the presence of three equivalents of piperidine, 4a was completely converted into the open-ring product 7a after 36 hours, whereas with morpholine only $72 \%$ of $\mathbf{7 b}$ were obtained after 60 hours (Scheme 6). The ring opening of the 8-azachromone scaffold in the presence of N-nucleophiles was reported in 2003 for 2polyfluoroalkyl derivatives. ${ }^{17}$ Curiously, in that case the reaction worked well with primary amines whereas piperidine and morpholine did not give open-ring products but the addition products 2-morpholino- and 2piperidino- 8-azachromanones instead.

\section{Scheme 6. Formation of Open-Ring Products by Two Consecutive Nucleophilic Substitutions.}<smiles>CC(=O)c1c(C)oc2nc(-c3ccccc3)cc(-c3ccccc3)c2c1=O</smiles>

$4 a$<smiles>[X]CCN(CC)C(C(C)=O)=C(C(=O)c1c(-c2ccccc2)cc(-c2ccccc2)[nH]c1=O)N1CCCCC1</smiles>

7

7a : $\mathrm{X}=\mathrm{CH}_{2}, 98 \%$

$7 b: X=0,72 \%$

The $N$ values of 13.5 and 12 mentioned above allow predicting the nucleophilic substitution with a given nucleophile and were exemplified for the 5,7-diphenyl derivative $\mathbf{4 a}$, playing the role of constant electrophile strength. Nevertheless, these data may also be applied to the $\mathrm{R}^{1}$-substituted derivatives $\mathbf{4 b}$-e as were observed that the presence of a para substituent on the 5-phenyl ring does not significantly affect the chemical properties of the azachromone core. This is revealed by comparing the ${ }^{13} \mathrm{C}$ chemical shifts of the azachromone scaffolds of compounds $\mathbf{4 b - e}$ with those of $\mathbf{4 a}$ (Table 3). Beside slight variations for carbon C5 (up to $1.3 \mathrm{ppm}$ ), the chemical shifts are almost identical, especially the chemical shifts of $\mathrm{C} 2$ and $\mathrm{C} 4$ (less than 0.4 ppm variations) which are directly connected to the electrophilicity. Therefore, compounds 4a-e can be considered of similar electrophile strengths and the limits in reactivity that were determined for $\mathbf{4 a}$ can be used with compounds $\mathbf{4 b - e}$ as well. 
Table 3. Influence of the $\mathrm{R}^{1}$ Substituents on the ${ }^{13} \mathrm{C}$ NMR Data of the 8-Azachromone Scaffold.

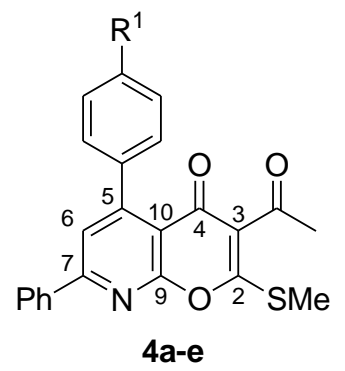

\begin{tabular}{ccccccccc}
\hline & \multicolumn{7}{c}{${ }^{13} C N M R\left(C D C l_{3}\right), \delta_{C}, p p m$} \\
\cline { 2 - 8 }$R^{l}$ & $C 2$ & $C 3$ & $C 4$ & $C 5$ & $C 6$ & $C 7$ & $C 9$ & $C 10$ \\
\hline $\mathbf{H}$ & $\mathbf{1 7 7 . 4}$ & $\mathbf{1 1 9 . 9}$ & $\mathbf{1 7 4 . 6}$ & $\mathbf{1 5 5 . 3}$ & $\mathbf{1 2 2 . 6}$ & $\mathbf{1 5 9 . 0}$ & $\mathbf{1 6 0 . 8}$ & $\mathbf{1 1 4 . 2}$ \\
$\mathrm{Cl}$ & 177.6 & 119.8 & 174.6 & 154.0 & 122.4 & 159.3 & 160.8 & 114.1 \\
$\mathrm{Br}$ & 177.6 & 119.8 & 174.5 & 154.0 & 122.3 & 159.3 & 160.8 & 114.0 \\
$\mathrm{O} t$-Bu & 177.1 & 119.9 & 174.7 & 155.1 & 122.7 & 158.9 & 160.9 & 114.2 \\
Morpholino & 177.1 & 119.9 & 175.0 & 155.1 & 122.5 & 158.8 & 161.1 & 114.0 \\
\hline
\end{tabular}

Scheme 7 shows examples of substitution products that were obtained from 4a-e according to the reaction conditions developed. Briefly, aliphatic primary amines were inserted in methylene chloride at room temperature (conditions A) whereas aromatic primary amines were inserted in dioxane at $85-100{ }^{\circ} \mathrm{C}$ in the presence of DMAP (conditions B). Enantiomerically pure amino acid methyl esters (phenylalanine, tyrosine, tryptophan and histidine) afforded substitution products according to conditions A with yields ranging from $43 \%$ to $81 \%$. Under the conditions of Scheme 7 , no significant racemization was observed and the products $6 \mathbf{a j - a m}$ and $\mathbf{6 b b}$ can almost be considered as enantiomerically pure (see specific rotations in the experimental section). This feature is interesting because most of amino acids and peptides have primary amino groups of similar nucleophilicities ${ }^{18}$ and, therefore, may be inserted to the 8 -azachromone scaffold in this way without loss of optical activity. 
Scheme 7. Nucleophilic Substitution of 4a-e with Primary Aliphatic and Aromatic Amines.
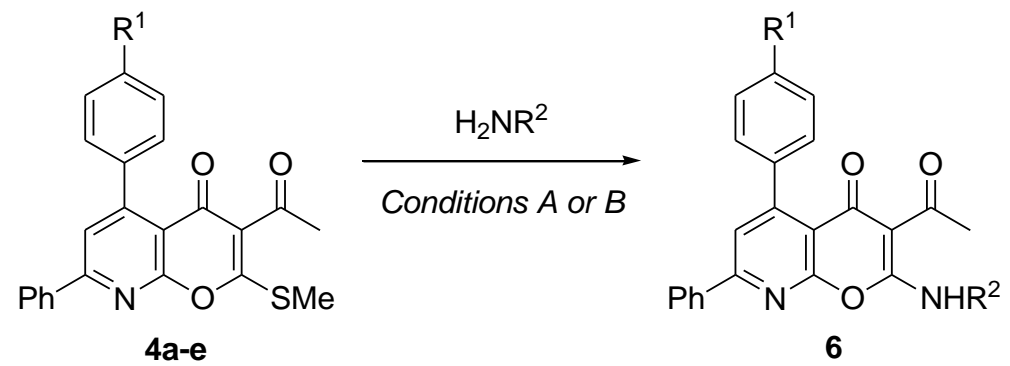<smiles>CC(=O)c1c(NC(Cc2ccccc2)C(C)=O)oc2nc(-c3ccccc3)cc(-c3ccccc3)c2c1=O</smiles>

6aj, $71 \%{ }^{a, c}$<smiles>CC(=O)c1c(NC(Cc2c[nH]cn2)C(C)=O)oc2nc(-c3ccccc3)cc(-c3ccccc3)c2c1=O</smiles>

6am, $43 \%$,<smiles>CC(=O)c1c(NC(Cc2ccc(O)cc2)C(C)=O)oc2nc(-c3ccccc3)cc(-c3ccccc3)c2c1=O</smiles>

6ak, $75 \%{ }^{a, c}$<smiles>CC(=O)c1c(NCc2ccccc2)oc2nc(-c3ccccc3)cc(-c3ccc(Cl)cc3)c2c1=O</smiles>

6ba, $98 \%^{a}$<smiles>CC(=O)c1c(NC(Cc2c[nH]c3ccccc23)C(C)=O)oc2nc(-c3ccccc3)cc(-c3ccccc3)c2c1=O</smiles>

6al, $81 \%{ }^{a, c}$<smiles>CC(=O)c1c(NC(Cc2ccc(O)cc2)C(C)=O)oc2nc(-c3ccccc3)cc(-c3ccc(Cl)cc3)c2c1=O</smiles>

6bb, $74 \%{ }^{a, c}$<smiles>CCOC(=O)c1ccc(Nc2oc3nc(-c4ccccc4)cc(-c4ccc(Cl)cc4)c3c(=O)c2C(C)=O)cc1</smiles><smiles>CNc1oc2nc(-c3ccccc3)cc(-c3ccc(Br)cc3)c2c(=O)c1C(C)=O</smiles>

6ca, $91 \%^{a}$

bbc, $61 \%^{b}$<smiles>CCCCOc1ccc(-c2cc(-c3ccccc3)nc3oc(NC)c(C(C)=O)c(=O)c23)cc1</smiles>

6da, $95 \%{ }^{a}$<smiles>CC(=O)c1c(NCc2ccccc2)oc2nc(-c3ccccc3)cc(-c3ccc(Br)cc3)c2c1=O</smiles>

$6 \mathrm{cb}, 89 \%^{a}$<smiles>CCOC(=O)c1ccc(Nc2oc3nc(-c4ccccc4)cc(-c4ccc(Br)cc4)c3c(=O)c2C(C)=O)cc1</smiles>

6cc, $67 \%$<smiles>CC(=O)c1c(NCc2ccccc2)oc2nc(-c3ccccc3)cc(-c3ccc(N4CCOCC4)cc3)c2c1=O</smiles>

6ea, $81 \%^{a}$<smiles>CC(=O)c1c(Nc2ccccc2)oc2nc(-c3ccccc3)cc(-c3ccc(N4CCOCC4)cc3)c2c1=O</smiles>

6eb, $89 \%^{b}$

$6 \mathrm{db}, 38 \%^{b}$

${ }^{a}$ Conditions A: $0.05-0.1 \mathrm{M} \mathrm{4,1.1}$ equiv amine, DCM, rt. ${ }^{b}$ Conditions B: $0.05 \mathrm{M} \mathrm{4,} 1.1$ equiv amine, 0.3 equiv DMAP, 1,4-dioxane, 85-100 ${ }^{\circ} \mathrm{C} .{ }^{c}$ Amino acid methyl ester generated from the corresponding hydrochloride (1.5 equiv) and $\mathrm{Et}_{3} \mathrm{~N}$ (1.1 equiv). ${ }^{d}$ Histidine methyl ester generated from the dihydrochloride (1.2 equiv) and $\mathrm{Et}_{3} \mathrm{~N}$ ( 2 equiv). 
So far, only $\mathrm{N}$-nucleophiles at least as nucleophilic as benzocaine enabled the formation of substitution products. When the $N$ value falls below the limit of $N 12$, the nucleophilic substitution does not take place. Accordingly, imidazole with $N 11.47$ is unreactive. However, imidazole is relatively acidic with a pKa of 18.6 in $\mathrm{DMSO}^{19}$ and, under anionic form, shows a significant increase in nucleophilicity to $N 21.09$ (data in DMSO), ${ }^{20}$ which is above the limit of reactivity. Thus, after deprotonation in the presence of $\mathrm{KO} t$ $\mathrm{Bu}$ in THF, the potassium salt of imidazole indeed reacts with $\mathbf{4 a}$ as predicted, but the product is quite unstable and unfortunately could not be isolated. However, primary amines of similar nucleophile strengths (i.e. unreactive under the conditions of Scheme 7), such as methyl and ethyl 5-aminopicolinate and 3aminoisoxazole, also react with $\mathbf{4 a}$ upon deprotonation by $\mathrm{KO}$ - $\mathrm{Bu}$ in THF, but this time give stable products that were isolated and clearly identified as substitution products 6an-ap (Scheme 8). The reaction is actually complicated by two distinctive features that cap the yields at 50\%: on the first hand, deprotonation of the substitution product by the amine anion that would require two equivalents for a complete conversion, but on the other hand the fast ring opening of the substitution product that prevents the use of a second equivalent of amine anion. Nevertheless, this strategy enables the formation of substitution products that would not be possible under neutral conditions, and was successfully applied to the $\mathrm{R}^{1}$-substituted derivatives 4b-e (Scheme 8). 
Scheme 8. Nucleophilic Substitution of 4a-e with Amine Anions. ${ }^{a}$
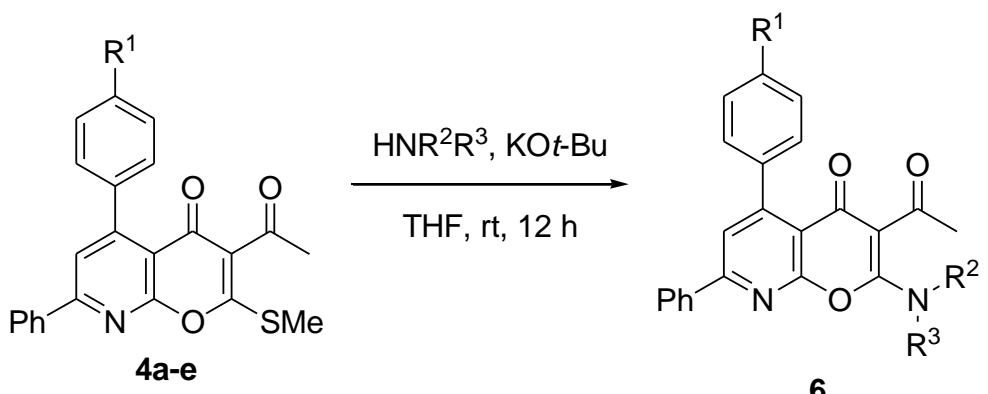

6<smiles>CC(=O)c1ccc(Nc2oc3nc(-c4ccccc4)cc(-c4ccccc4)c3c(=O)c2C(C)=O)cn1</smiles>

6an, $41 \%$<smiles>CCOC(=O)c1ccc(Nc2oc3nc(-c4ccccc4)cc(-c4ccccc4)c3c(=O)c2C(C)=O)cn1</smiles>

$6 a 0,47 \%$<smiles>CC(=O)c1c(Nc2ccon2)oc2nc(-c3ccccc3)cc(-c3ccccc3)c2c1=O</smiles>

6ap, 38\%<smiles>CCOC(=O)c1ccc(Nc2oc3nc(-c4ccccc4)cc(-c4ccc(Cl)cc4)c3c(=O)c2C(C)=O)cn1</smiles>

6 bd, $46 \%$<smiles>CCOC(=O)c1ccc(Nc2oc3nc(-c4ccccc4)cc(-c4ccc(Br)cc4)c3c(=O)c2C(C)=O)cn1</smiles>

$6 \mathrm{~cd}, 48 \%$<smiles>CCC(C)Oc1ccc(-c2cc(-c3ccccc3)nc3oc(Nc4ccc(C(C)=O)nc4)c(C(C)=O)c(=O)c23)cc1</smiles>

6 dc, $49 \%$<smiles>CC(=O)c1ccc(Nc2oc3nc(-c4ccccc4)cc(-c4ccc(N5CCOCC5)cc4)c3c(=O)c2C(C)=O)cn1</smiles>

6 ec, $36 \%$

${ }^{a}$ Reaction conditions: $0.05 \mathrm{M} \mathrm{4,} 1.5$ equiv amine, 1.1 equiv $\mathrm{KO} t$-Bu, anhyd THF, rt, argon atm.

The activation via deprotonation, which is possible with $\mathrm{N}$-nucleophiles, might not be effective for other classes of nucleophiles as the basicity of the reaction medium has to be taken into consideration. For example, the O-nucleophiles water $(N$ 5.20) and methanol ( $N$ 7.54) would need deprotonation to give substitution products. However, the corresponding hydroxide and methoxide anions are much more basic than the amine anions used in Scheme 8, and thus deprotonate the 2-(methylthio)-8-azachromone starting materials, resulting in more difficult reactions. Nevertheless, neutral nucleophiles of any class with $N$ values above 12 in the Mayr's nucleophilicity scale (e.g. enamines) should give the corresponding substitution products in the same way than $\mathrm{N}$-nucleophiles do. 
We have developed an efficient strategy enabling the synthesis of 2-(substituted amino)-8azachromones. This strategy relies on three main steps: the synthesis of 3-acetoacetyl derivatives of 4,6diaryl-2-pyridones, their cyclization into 2-(methylthio)-8-azachromones via condensation with carbon disulfide, and finally the insertion of amines at C2 by nucleophilic substitution. Three main classes of amines have been distinguished according to the conditions promoting the nucleophilic substitution, which in turn depend on the nucleophile strength. The position of a given amine into one of those three classes is easily predicted by using the Mayr's nucleophilicity scale. Because the nucleophilic substitution is not altered by the presence of a para substituent on the 5-phenyl ring, numerous structural analogs can be designed. Our synthetic strategy paves the way for a greater access to new compounds of possible pharmaceutical interest. This may be driven by the pharmaceutical properties of many N-substituted 2amino-chromones, including anti-platelet aggregation, kinase inhibition in anti-cancer therapies, antiinflammatory and antibacterial drugs. ${ }^{3 a, 21}$

\section{EXPERIMENTAL SECTION}

General remarks. Commercially available reagents and solvents were used as purchased without further purification, unless otherwise indicated. ${ }^{1} \mathrm{H}$ and ${ }^{13} \mathrm{C}$ NMR spectra were recorded on $400 \mathrm{MHz}, 500$ $\mathrm{MHz}$ and $600 \mathrm{MHz}$ instruments, and were calibrated using residual solvent signals as internal references: $\delta_{\mathrm{H}}$ $7.26 \mathrm{ppm}$ and $\delta_{\mathrm{C}} 77.16 \mathrm{ppm}$ for $\mathrm{CDCl}_{3}, \delta_{\mathrm{H}} 2.50 \mathrm{ppm}$ and $\delta_{\mathrm{C}} 39.52 \mathrm{ppm}$ for DMSO- $d_{6} .{ }^{1} \mathrm{H}$ NMR data are reported as follows: chemical shift $(\mathrm{ppm})$, multiplicity $(\mathrm{s}=$ singlet, $\mathrm{d}=$ doublet, $\mathrm{t}=$ triplet, $\mathrm{q}=$ quartet, $\mathrm{m}=$ multiplet, br $=$ broad signal), coupling constants and integration. Proton-decoupled ${ }^{13} \mathrm{C}$ NMR data are reported in terms of chemical shifts with unresolved signals of chemically distinct carbons indicated. Structural assignments were made with additional information from gCOSY, gHSQC, and gHMBC experiments. High resolution mass spectra were recorded on a micrOTOF-Q instrument using electrospray ionization (ESI) in positive or negative ion polarity mode. Analytical thin-layer chromatography was performed with commercial plates of silica gel 60, visualized with short wavelength UV light (254 nm) and stained with a $p$-anisaldehyde solution in $\mathrm{EtOH} / \mathrm{H}_{2} \mathrm{SO}_{4}$ with subsequent heating. Preparative flash chromatography was performed with silica gel 60 . Reactions that required heating were performed in hot plate/heating block apparatus with internal temperature control.

General procedure for the synthesis of 4-susbtituted chalcones. To a stirred solution of 4substituted benzaldehyde $(6 \mathrm{mmol})$ and acetophenone $(0.7 \mathrm{~mL}, 6 \mathrm{mmol})$ in absolute ethanol $(18 \mathrm{~mL}), \mathrm{NaOH}$ (15 $\mathrm{M}$ aq solution, $0.6 \mathrm{~mL}, 9 \mathrm{mmol}$ ) was added and the resulting reaction mixture was stirred $20 \mathrm{~h}$ at $\mathrm{rt}$. After completion, the reaction mixture was diluted with absolute ethanol $(18 \mathrm{~mL})$ and cooled to $0{ }^{\circ} \mathrm{C}$. The precipitated product was recovered by filtration, washed with cold absolute ethanol and dried under vacuum.

4-Chlorochalcone was commercially available. 
4-Bromochalcone was prepared from 4-bromobenzaldehyde according to the general procedure. $1.33 \mathrm{~g}$ (4.63 mmol, 77\% yield), pale yellow solid. The spectroscopic data were consistent with those reported. ${ }^{22}$

4-t-Butoxychalcone was prepared from 4-t-butoxybenzaldehyde according to the general procedure.

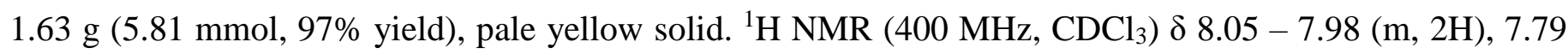
$(\mathrm{d}, J=15.7 \mathrm{~Hz}, 1 \mathrm{H}), 7.61-7.54(\mathrm{~m}, 3 \mathrm{H}), 7.53-7.48(\mathrm{~m}, 2 \mathrm{H}), 7.44(\mathrm{~d}, J=15.7 \mathrm{~Hz}, 1 \mathrm{H}), 7.03(\mathrm{dm}, J=8.6$ $\mathrm{Hz}, 2 \mathrm{H}), 1.40$ (s, 9H). ${ }^{13} \mathrm{C}\left\{{ }^{1} \mathrm{H}\right\} \mathrm{NMR}\left(101 \mathrm{MHz}, \mathrm{CDCl}_{3}\right) \delta 190.8,158.3,144.8,138.6,132.8,129.8,129.6$, 128.7, 128.6, 123.9, 120.8, 79.6, 29.1. HRMS (ESI/Q-TOF) $m / z:[\mathrm{M}+\mathrm{H}]^{+}$calcd for $\mathrm{C}_{19} \mathrm{H}_{21} \mathrm{O}_{2} 281.1536$, found 281.1528 .

4-Morpholinochalcone was prepared from 4-morpholinobenzaldehyde according to the general procedure. $1.54 \mathrm{~g}$ (5.25 mmol, 87\% yield), yellow solid. ${ }^{1} \mathrm{H}$ NMR (400 MHz, $\left.\mathrm{CDCl}_{3}\right) \delta 8.04-7.96(\mathrm{~m}, 2 \mathrm{H})$, $7.78(\mathrm{~d}, J=15.6 \mathrm{~Hz}, 1 \mathrm{H}), 7.62-7.53(\mathrm{~m}, 3 \mathrm{H}), 7.53-7.46(\mathrm{~m}, 2 \mathrm{H}), 7.39(\mathrm{~d}, J=15.6 \mathrm{~Hz}, 1 \mathrm{H}), 6.92(\mathrm{dm}, J=$ $8.8 \mathrm{~Hz}, 2 \mathrm{H}), 3.91-3.84(\mathrm{~m}, 4 \mathrm{H}), 3.31-3.25(\mathrm{~m}, 4 \mathrm{H}) .{ }^{13} \mathrm{C}\left\{{ }^{1} \mathrm{H}\right\}$ NMR $\left(101 \mathrm{MHz}, \mathrm{CDCl}_{3}\right) \delta 190.8,152.7$, 145.1, 138.9, 132.6, 130.3, 128.7, 128.5, 126.2, 119.0, 115.0, 66.7, 48.3. HRMS (ESI/Q-TOF) $m / z:[\mathrm{M}+\mathrm{H}]^{+}$ calcd for $\mathrm{C}_{19} \mathrm{H}_{20} \mathrm{NO}_{2} 294.1494$, found 294.1494.

General procedure for the synthesis of 4,6-diaryl-3-cyano-2-pyridones 1a-e-K (Table 1). To a stirred solution of chalcone $(2 \mathrm{mmol})$ and cyanoacetamide $(185 \mathrm{mg}, 2.2 \mathrm{mmol})$ in the indicated alcohol $(t$ butyl alcohol or 2-propanol, $24 \mathrm{~mL}), \mathrm{KO} t$-Bu $(898 \mathrm{mg}, 8 \mathrm{mmol})$ was added in one portion and the resulting reaction mixture was stirred in open air under the indicated conditions. After completion, 2-propanol (24 $\mathrm{mL}$ ) was added and the stirring was kept $15 \mathrm{~min}$ at $\mathrm{rt}$. The precipitated product was recovered by filtration, washed with successively 2-propanol (3 x $24 \mathrm{~mL})$, cyclohexane $(3 \times 12 \mathrm{~mL})$ and $\mathrm{Et}_{2} \mathrm{O}(3 \times 12 \mathrm{~mL})$, and dried under vacuum. The products were characterized as potassium salts. The neutral forms $\mathbf{1 a}{ }^{23,24} \mathbf{1 b}^{23,25}$ and $\mathbf{1} \mathbf{c}^{25,26}$ have been reported.

3-Cyano-4,6-diphenyl-2(1H)-pyridone, potassium salt (1a-K) was prepared from trans-chalcone according to the general procedure (2-propanol, rt, $60 \mathrm{~h}$ ). $595 \mathrm{mg}$ (1.92 mmol, 96\% yield), pale yellow solid. ${ }^{1} \mathrm{H}$ NMR (400 MHz, DMSO-d6) $\delta 7.97(\mathrm{dm}, J=6.9 \mathrm{~Hz}, 2 \mathrm{H}), 7.57(\mathrm{dm}, J=6.9 \mathrm{~Hz}, 2 \mathrm{H}), 7.51-7.32(\mathrm{~m}$, $6 \mathrm{H}), 6.53(\mathrm{~s}, 1 \mathrm{H}) .{ }^{13} \mathrm{C}\left\{{ }^{1} \mathrm{H}\right\} \mathrm{NMR}\left(101 \mathrm{MHz}, \mathrm{DMSO}-d_{6}\right) \delta 172.2,158.9,154.6,140.3,139.3,128.5,128.3$ (2C), 128.2, 128.0, 126.8, 121.5, 101.8, 91.2. HRMS (ESI/Q-TOF) $m / z:[\mathrm{M}-\mathrm{K}]^{-}$calcd for $\mathrm{C}_{18} \mathrm{H}_{11} \mathrm{~N}_{2} \mathrm{O}$ 271.0871, found 271.0871.

4-(4-Chlorophenyl)-3-cyano-6-phenyl-2(1H)-pyridone, potassium salt (1b-K) was prepared from 4-chlorochalcone according to the general procedure (2-propanol, rt, $60 \mathrm{~h}) .643 \mathrm{mg}$ (1.86 mmol, 93\% yield), pale yellow solid. ${ }^{1} \mathrm{H}$ NMR (400 MHz, DMSO- $\left.d_{6}\right) \delta 8.00-7.93(\mathrm{~m}, 2 \mathrm{H}), 7.59(\mathrm{dm}, J=8.6 \mathrm{~Hz}, 2 \mathrm{H}), 7.53$ $(\mathrm{dm}, J=8.6 \mathrm{~Hz}, 2 \mathrm{H}), 7.43-7.32(\mathrm{~m}, 3 \mathrm{H}), 6.52(\mathrm{~s}, 1 \mathrm{H}) .{ }^{13} \mathrm{C}\left\{{ }^{1} \mathrm{H}\right\} \mathrm{NMR}\left(101 \mathrm{MHz}, \mathrm{DMSO}-d_{6}\right) \delta 172.0$, 
159.1, 153.3, 140.2, 138.1, 133.1, 129.9, 128.6, 128.4, 128.2, 126.8, 121.3, 101.6, 91.0. HRMS (ESI/QTOF) $m / z:[\mathrm{M}-\mathrm{K}]^{-}$calcd for $\mathrm{C}_{18} \mathrm{H}_{10} \mathrm{ClN}_{2} \mathrm{O} 305.0482$, found 305.0477 .

4-(4-Bromophenyl)-3-cyano-6-phenyl-2(1H)-pyridone, potassium salt (1c-K) was prepared from 4-bromochalcone according to the general procedure (2-propanol, rt, $60 \mathrm{~h}$ ). $747 \mathrm{mg}$ (1.92 mmol, 96\% yield), pale yellow solid. ${ }^{1} \mathrm{H}$ NMR (400 MHz, DMSO- $\left.d_{6}\right) \delta 8.00-7.93(\mathrm{~m}, 2 \mathrm{H}), 7.66(\mathrm{dm}, J=8.5 \mathrm{~Hz}, 2 \mathrm{H}), 7.52$ $(\mathrm{dm}, J=8.5 \mathrm{~Hz}, 2 \mathrm{H}), 7.43-7.32(\mathrm{~m}, 3 \mathrm{H}), 6.53(\mathrm{~s}, 1 \mathrm{H}) .{ }^{13} \mathrm{C}\left\{{ }^{1} \mathrm{H}\right\}$ NMR (101 MHz, DMSO-d6) $\delta$ 172.3, $159.5,153.8,140.1,138.4,131.6,130.4,129.0,128.5,127.1,122.1,121.2$, 102.7, 91.4. HRMS (ESI/QTOF) $m / z:[\mathrm{M}-\mathrm{K}]^{-}$calcd for $\mathrm{C}_{18} \mathrm{H}_{10}{ }^{79} \mathrm{BrN}_{2} \mathrm{O} 348.9982$, found 348.9992 ; calcd for $\mathrm{C}_{18} \mathrm{H}_{10}{ }^{81} \mathrm{BrN}_{2} \mathrm{O}$ 350.9956, found 350.9980 .

4-(4-t-Butoxyphenyl)-3-cyano-6-phenyl-2(1H)-pyridone, potassium salt (1d-K) was prepared from 4-t-butoxychalcone according to the general procedure (2-propanol, rt, $60 \mathrm{~h}$ ). $589 \mathrm{mg}(1.54 \mathrm{mmol}, 77 \%$ yield), white solid. ${ }^{1} \mathrm{H}$ NMR (400 MHz, DMSO- $\left.d_{6}\right) \delta 8.00-7.94(\mathrm{~m}, 2 \mathrm{H}), 7.51(\mathrm{dm}, J=8.6 \mathrm{~Hz}, 2 \mathrm{H}), 7.43-$ $7.31(\mathrm{~m}, 3 \mathrm{H}), 7.05(\mathrm{dm}, J=8.6 \mathrm{~Hz}, 2 \mathrm{H}), 6.51(\mathrm{~s}, 1 \mathrm{H}), 1.35(\mathrm{~s}, 9 \mathrm{H}) .{ }^{13} \mathrm{C}\left\{{ }^{1} \mathrm{H}\right\} \mathrm{NMR}\left(101 \mathrm{MHz}, \mathrm{DMSO}-d_{6}\right) \delta$ 172.2, 158.8, 155.4, 154.1, 140.4, 133.7, 128.8, 128.4, 128.1, 126.8, 122.9, 121.7, 101.7, 91.1, 78.3, 28.6. HRMS (ESI/Q-TOF) $m / z:[\mathrm{M}-\mathrm{K}]^{-}$calcd for $\mathrm{C}_{22} \mathrm{H}_{19} \mathrm{~N}_{2} \mathrm{O}_{2} 343.1447$, found 343.1443.

3-Cyano-4-(4-morpholinophenyl)-6-phenyl-2(1H)-pyridone, potassium salt (1e-K) was prepared from 4-morpholinochalcone according to the general procedure ( $t$-butyl alcohol, $\left.30{ }^{\circ} \mathrm{C}, 48 \mathrm{~h}\right) .734 \mathrm{mg}(1.86$ mmol, 93\% yield), pale yellow solid. ${ }^{1} \mathrm{H}$ NMR (400 MHz, DMSO- $\left.d_{6}\right) \delta 8.01-7.91(\mathrm{~m}, 2 \mathrm{H}), 7.49$ (d, $J=8.8$ $\mathrm{Hz}, 2 \mathrm{H}), 7.43-7.31(\mathrm{~m}, 3 \mathrm{H}), 7.01(\mathrm{~d}, J=8.8 \mathrm{~Hz}, 2 \mathrm{H}), 6.50(\mathrm{~s}, 1 \mathrm{H}), 3.79-3.73(\mathrm{~m}, 4 \mathrm{H}), 3.22-3.15(\mathrm{~m}$, $4 \mathrm{H}) .{ }^{13} \mathrm{C}\left\{{ }^{1} \mathrm{H}\right\}$ NMR (101 MHz, DMSO-d $) \delta 172.4,158.7,154.4,151.1,140.5,129.5,128.8,128.4,128.1$, 126.8, 121.9, 114.4, 101.6, 90.9, 66.1, 48.0. HRMS (ESI/Q-TOF) $m / z:[\mathrm{M}-\mathrm{K}]^{-}$calcd for $\mathrm{C}_{22} \mathrm{H}_{18} \mathrm{~N}_{3} \mathrm{O}_{2}$ 356.1405 , found 356.1408 .

General procedure for the synthesis of 3-acetyl-4,6-diaryl-2-pyridones 2a-e (Scheme 2). To a stirred suspension of 3-cyano-2-pyridone 1-K $(2 \mathrm{mmol})$ in anhydrous THF $(10 \mathrm{~mL})$ under argon atmosphere, anhydrous 1,4-dioxane $(1 \mathrm{~mL}, 12 \mathrm{mmol})$ was added and the mixture was cooled to $0{ }^{\circ} \mathrm{C}$. Then, $\mathrm{MeMgBr}\left(3 \mathrm{M}\right.$ solution in $\mathrm{Et}_{2} \mathrm{O}, 4 \mathrm{~mL}, 12 \mathrm{mmol}$ ) was slowly added and the resulting reaction mixture was stirred $48 \mathrm{~h}$ while allowed to reach $\mathrm{rt}$. After completion, $4 \mathrm{~mL} \mathrm{H}_{2} \mathrm{O}$ were added dropwise at $0{ }^{\circ} \mathrm{C}$ followed by $14 \mathrm{~mL}$ of $1 \mathrm{~N}$ aq $\mathrm{HCl}(14 \mathrm{mmol} \mathrm{HCl})$. The resulting mixture was stirred $12 \mathrm{~h}$ at $40^{\circ} \mathrm{C}$. Finally, most of the THF was evaporated under reduced pressure, an excess volume of $0.1 \mathrm{~N}$ aq $\mathrm{HCl}$ was added and the product was extracted with DCM. The combined organic layers were washed with successively $0.1 \mathrm{~N}$ aq $\mathrm{HCl}, \mathrm{H}_{2} \mathrm{O}$ and brine, dried over $\mathrm{Na}_{2} \mathrm{SO}_{4}$ and concentrated. The crude product containing 4-8\% of the starting 3-cyano2-pyridone (neutral form) was precipitated in petroleum ether, recovered by filtration, dried under vacuum and used without further purification (analytical samples were obtained by flash chromatography on silica gel). 
3-Acetyl-4,6-diphenyl-2(1H)-pyridone (2a) was prepared from 1a-K according to the general procedure. $434 \mathrm{mg}$ (1.5 mmol, 75\% yield), orange solid. An analytical sample was obtained by flash chromatography (DCM/EtOAc 85:15 then DCM/EtOAc/EtOH 85:10:5). The spectroscopic data were consistent with those reported. ${ }^{27}$

3-Acetyl-4-(4-chlorophenyl)-6-phenyl-2(1H)-pyridone (2b) was prepared from $\mathbf{1 b}-\mathbf{K}$ according to the general procedure. $440 \mathrm{mg}$ (1.36 mmol, 68\% yield), yellowish solid. An analytical sample was obtained by flash chromatography (DCM/EtOAc 80:20 then DCM/EtOAc/EtOH 80:15:5). ${ }^{1} \mathrm{H}$ NMR (500 MHz, $\left.\mathrm{CDCl}_{3}\right) \delta 12.36($ br s, $1 \mathrm{H}), 7.82-7.77(\mathrm{~m}, 2 \mathrm{H}), 7.54-7.48(\mathrm{~m}, 3 \mathrm{H}), 7.41(\mathrm{dm}, J=8.5 \mathrm{~Hz}, 2 \mathrm{H}), 7.30(\mathrm{dm}, J$ $=8.5 \mathrm{~Hz}, 2 \mathrm{H}), 6.54(\mathrm{~s}, 1 \mathrm{H}), 2.43(\mathrm{~s}, 3 \mathrm{H}) .{ }^{13} \mathrm{C}\left\{{ }^{1} \mathrm{H}\right\} \mathrm{NMR}\left(126 \mathrm{MHz}, \mathrm{CDCl}_{3}\right) \delta 202.0,162.9,152.6,148.1$, 136.8, 135.4, 132.7, 131.1, 129.42, 129.36, 129.1, 127.8 (br), 127.0, 107.6, 32.0. HRMS (ESI/Q-TOF) $\mathrm{m} / z$ : $[\mathrm{M}+\mathrm{H}]^{+}$calcd for $\mathrm{C}_{19} \mathrm{H}_{15} \mathrm{ClNO}_{2} 324.0791$, found 324.0792.

3-Acetyl-4-(4-bromophenyl)-6-phenyl-2(1H)-pyridone (2c) was prepared from 1c-K according to the general procedure. $479 \mathrm{mg}(1.30 \mathrm{mmol}, 65 \%$ yield), yellowish solid. An analytical sample was obtained by flash chromatography (DCM/EtOAc 80:20 then DCM/EtOAc/EtOH 80:15:5). ${ }^{1} \mathrm{H}$ NMR (400 MHz, DMSO-d $d_{6} \delta 12.03($ br s, $1 \mathrm{H}), 7.90-7.80(\mathrm{~m}, 2 \mathrm{H}), 7.63(\mathrm{dm}, J=8.5 \mathrm{~Hz}, 2 \mathrm{H}), 7.53-7.48(\mathrm{~m}, 3 \mathrm{H}), 7.35$ $(\mathrm{dm}, J=8.5 \mathrm{~Hz}, 2 \mathrm{H}), 6.62$ (br s, $1 \mathrm{H}), 2.42$ (s, 3H). ${ }^{13} \mathrm{C}\left\{{ }^{1} \mathrm{H}\right\} \mathrm{NMR}\left(126 \mathrm{MHz}, \mathrm{DMSO}-d_{6}\right) \delta 202.4,161.2$, 150.2, 148.0 (br), 137.3, 133.0 (br), 131.6, 130.4 (2C), 130.2, 128.9, 127.4, 122.3, 106.7 (br), 31.8. HRMS (ESI/Q-TOF) $m / z:[\mathrm{M}+\mathrm{H}]^{+}$calcd for $\mathrm{C}_{19} \mathrm{H}_{15}{ }^{79} \mathrm{BrNO}_{2} 368.0286$, found 368.0288.

3-Acetyl-4-(4-t-butoxyphenyl)-6-phenyl-2(1H)-pyridone (2d) was prepared from $1 \mathrm{~d}-\mathrm{K}$ according to the general procedure. $405 \mathrm{mg}(1.12 \mathrm{mmol}, 56 \%$ yield), yellowish solid. An analytical sample was obtained by flash chromatography (DCM/EtOAc 80:20 then DCM/EtOAc/EtOH 80:15:5). ${ }^{1} \mathrm{H}$ NMR (400 $\left.\mathrm{MHz}, \mathrm{CDCl}_{3}\right) \delta 12.90$ (br s, 1H), $7.88-7.81(\mathrm{~m}, 2 \mathrm{H}), 7.53-7.46(\mathrm{~m}, 3 \mathrm{H}), 7.29(\mathrm{dm}, J=8.6 \mathrm{~Hz}, 2 \mathrm{H}), 7.04$ $(\mathrm{dm}, J=8.6 \mathrm{~Hz}, 2 \mathrm{H}), 6.62(\mathrm{~s}, 1 \mathrm{H}), 2.35(\mathrm{~s}, 3 \mathrm{H}), 1.39(\mathrm{~s}, 9 \mathrm{H}) .{ }^{13} \mathrm{C}\left\{{ }^{1} \mathrm{H}\right\} \mathrm{NMR}\left(101 \mathrm{MHz}, \mathrm{CDCl}_{3}\right) \delta 202.5$, 163.2, 156.8, 152.9, 147.6, 133.0, 132.8, 130.8, 129.3, 129.0, 127.8, 127.2, 123.9, 107.8, 79.2, 31.8, 29.0. HRMS (ESI/Q-TOF) $m / z:[\mathrm{M}+\mathrm{H}]^{+}$calcd for $\mathrm{C}_{23} \mathrm{H}_{24} \mathrm{NO}_{3} 362.1751$, found 362.1759 .

3-Acetyl-4-(4-morpholinophenyl)-6-phenyl-2(1H)-pyridone (2e) was prepared from 1e-K according to the general procedure. $454 \mathrm{mg}$ (1.21 mmol, 61\% yield), orange solid. An analytical sample was obtained by flash chromatography (DCM/EtOAc 70:30 then DCM/EtOAc/EtOH 70:25:5). ${ }^{1} \mathrm{H}$ NMR (400 $\left.\mathrm{MHz}, \mathrm{CDCl}_{3}\right) \delta 12.58($ br s, $1 \mathrm{H}), 7.86-7.78(\mathrm{~m}, 2 \mathrm{H}), 7.54-7.46(\mathrm{~m}, 3 \mathrm{H}), 7.31(\mathrm{dm}, J=8.8 \mathrm{~Hz}, 2 \mathrm{H}), 6.92$ $(\mathrm{dm}, J=8.8 \mathrm{~Hz}, 2 \mathrm{H}), 6.60(\mathrm{~s}, 1 \mathrm{H}), 3.90-3.84(\mathrm{~m}, 4 \mathrm{H}), 3.29-3.19(\mathrm{~m}, 4 \mathrm{H}), 2.38(\mathrm{~s}, 3 \mathrm{H}) .{ }^{13} \mathrm{C}\left\{{ }^{1} \mathrm{H}\right\} \mathrm{NMR}$ $\left(101 \mathrm{MHz} \mathrm{CDCl}_{3}\right) \delta 202.9,163.1,152.8,151.8,147.5,133.1,130.7,129.4,129.3,128.8,127.3,127.1$, 115.1, 107.7, 66.9, 48.5, 31.9. HRMS (ESI/Q-TOF) $m / z:[\mathrm{M}+\mathrm{H}]^{+}$calcd for $\mathrm{C}_{23} \mathrm{H}_{23} \mathrm{~N}_{2} \mathrm{O}_{3} 375.1703$, found 375.1692 . 
General procedure for the synthesis of 1,3-diketones 3a-e (Scheme 2). 3-Acetyl-2-pyridone 2 (2 $\mathrm{mmol})$ and $\mathrm{NaH}(60 \%$ dispersion in mineral oil, $12 \mathrm{mmol}, 480 \mathrm{mg}$ ) were suspended in anhydrous 1,4dioxane $(8 \mathrm{~mL})$ under argon atmosphere, and stirred $1 \mathrm{~h}$ at $\mathrm{rt}$. Then, EtOAc $(2 \mathrm{~mL}, 20.5 \mathrm{mmol}$, see note below) was added and the resulting reaction mixture was stirred $12 \mathrm{~h}$ at $\mathrm{rt}$. After completion, the reaction was diluted with EtOAc and quenched at $0{ }^{\circ} \mathrm{C}$ by slow addition of an excess volume of saturated aq $\mathrm{NH}_{4} \mathrm{Cl}$. The organic layer was separated and the aqueous layer was extracted again with EtOAc. The combined organic layers were washed with saturated aq $\mathrm{NH}_{4} \mathrm{Cl}$, dried over $\mathrm{Na}_{2} \mathrm{SO}_{4}$ and concentrated. The product was isolated by chromatography on silica gel and then precipitated by addition of the indicated solvent. Enol/keto ratios were determined by ${ }^{1} \mathrm{H} \mathrm{NMR}$ in $\mathrm{CDCl}_{3}$. Note: commercial grade EtOAc was dried over $\mathrm{CaCl}_{2}$ overnight, then filtered through a cotton plug and stored over $4 \dot{A}$ molecular sieves until used.

3-Acetoacetyl-4,6-diphenyl-2(1H)-pyridone (3a) was prepared from $2 \mathbf{a}$ according to the general procedure and was isolated by flash chromatography (DCM/EtOAc 85:15 then DCM/EtOAc/EtOH 85:10:5). $557 \mathrm{mg}$ (1.68 mmol, 84\% yield), yellowish solid (cyclohexane). Ratio enol/keto 3.6:1. ${ }^{1} \mathrm{H}$ NMR (400 MHz, $\mathrm{CDCl}_{3}$, enol form) $\delta 15.41$ (br s, $\left.1 \mathrm{H}\right), 12.80$ (br s, $\left.1 \mathrm{H}\right), 7.89-7.80(\mathrm{~m}, 2 \mathrm{H}), 7.56-7.36$ (m, 8H), 6.63 (s, $1 \mathrm{H}), 5.86(\mathrm{~s}, 1 \mathrm{H}), 2.02(\mathrm{~s}, 3 \mathrm{H}) .{ }^{1} \mathrm{H}$ NMR $\left(400 \mathrm{MHz} \mathrm{CDCl}_{3}\right.$, keto form) $\delta 12.80(\mathrm{br} \mathrm{s}, 1 \mathrm{H}), 7.89-7.80(\mathrm{~m}$, $2 \mathrm{H}), 7.56-7.36(\mathrm{~m}, 8 \mathrm{H}), 6.60(\mathrm{~s}, 1 \mathrm{H}), 3.96(\mathrm{~s}, 2 \mathrm{H}), 2.00(\mathrm{~s}, 3 \mathrm{H}) .{ }^{13} \mathrm{C}\left\{{ }^{1} \mathrm{H}\right\} \mathrm{NMR}\left(101 \mathrm{MHz}, \mathrm{CDCl}_{3}\right.$, enol form) $\delta 191.4,184.9,163.1,154.9,147.8,139.0,132.9,130.9,129.3,129.0$ (2C), 128.7, 127.9, 127.2, 108.1, 104.2, 25.3. HRMS (ESI/Q-TOF) $m / z:[\mathrm{M}-\mathrm{H}]^{-}$calcd for $\mathrm{C}_{21} \mathrm{H}_{16} \mathrm{NO}_{3} 330.1130$, found 330.1123.

3-Acetoacetyl-4-(4-chlorophenyl)-6-phenyl-2(1H)-pyridone (3b) was prepared from $3 \mathrm{~b}$ according to the general procedure and was isolated by flash chromatography (DCM/EtOAc 80:20 then DCM/EtOAc/EtOH 80:15:5). $578 \mathrm{mg}$ (1.58 mmol, 79\% yield), yellowish solid (cyclohexane). Ratio enol/keto 3.7:1. ${ }^{1} \mathrm{H}$ NMR (400 MHz, $\mathrm{CDCl}_{3}$, enol form) $\delta 15.40$ (br s, 1H), 12.60 (br s, 1H), $7.86-7.76$ (m, 2H), $7.55-7.45(\mathrm{~m}, 3 \mathrm{H}), 7.43-7.32(\mathrm{~m}, 4 \mathrm{H}), 6.56(\mathrm{~s}, 1 \mathrm{H}), 5.90(\mathrm{~s}, 1 \mathrm{H}), 2.05(\mathrm{~s}, 3 \mathrm{H}) .{ }^{1} \mathrm{H}$ NMR $(400 \mathrm{MHz}$, $\mathrm{CDCl}_{3}$, keto form) $\delta 12.60$ (br s, $\left.1 \mathrm{H}\right), 7.86-7.76(\mathrm{~m}, 2 \mathrm{H}), 7.55-7.45(\mathrm{~m}, 3 \mathrm{H}), 7.43-7.32(\mathrm{~m}, 4 \mathrm{H}), 6.53$ (s, $1 \mathrm{H}), 4.00(\mathrm{~s}, 2 \mathrm{H}), 2.00(\mathrm{~s}, 3 \mathrm{H}) .{ }^{13} \mathrm{C}\left\{{ }^{1} \mathrm{H}\right\} \mathrm{NMR}\left(101 \mathrm{MHz}, \mathrm{CDCl}_{3}\right.$, enol form) $\delta 191.6,184.5,162.9,153.7$, 148.0, 137.4, 135.2, 132.7, 131.0, 129.4, 129.3, 129.0, 127.4, 127.1, 107.7, 104.1, 25.4. HRMS (ESI/QTOF) $m / z:[\mathrm{M}+\mathrm{H}]^{+}$calcd for $\mathrm{C}_{21} \mathrm{H}_{17} \mathrm{ClNO}_{3} 366.0897$, found 366.0894 .

3-Acetoacetyl-4-(4-bromophenyl)-6-phenyl-2(1H)-pyridone (3c) was prepared from 2c according to the general procedure and was isolated by flash chromatography (DCM/EtOAc 80:20 then DCM/EtOAc/EtOH 80:15:5). $591 \mathrm{mg}$ (1.44 mmol, 72\% yield), yellowish solid (cyclohexane). Ratio enol/keto 3.4:1. ${ }^{1} \mathrm{H}$ NMR (400 MHz, $\mathrm{CDCl}_{3}$, enol form) $\delta 15.38$ (br s, $1 \mathrm{H}$ ), 11.94 (br s, 1H), $7.82-7.73$ (m, 2H), $7.55(\mathrm{dm}, J=8.5 \mathrm{~Hz}, 2 \mathrm{H}), 7.58-7.46(\mathrm{~m}, 3 \mathrm{H}), 7.30(\mathrm{dm}, J=8.5 \mathrm{~Hz}, 2 \mathrm{H}), 6.55(\mathrm{~s}, 1 \mathrm{H}), 5.89(\mathrm{~s}, 1 \mathrm{H})$, 2.05 (s, 3H). ${ }^{1} \mathrm{H}$ NMR (400 MHz, $\mathrm{CDCl}_{3}$, keto form) $\delta 11.94$ (br s, 1H), $7.82-7.73(\mathrm{~m}, 2 \mathrm{H}), 7.58-7.46$ (m, $5 \mathrm{H}), 7.33-7.24(\mathrm{~m}, 2 \mathrm{H}), 6.51(\mathrm{~s}, 1 \mathrm{H}), 4.01(\mathrm{~s}, 2 \mathrm{H}), 2.04(\mathrm{~s}, 3 \mathrm{H}) \cdot{ }^{13} \mathrm{C}\left\{{ }^{1} \mathrm{H}\right\} \mathrm{NMR}\left(101 \mathrm{MHz}, \mathrm{CDCl}_{3}\right.$, enol form) $\delta 191.7,184.5,162.6,153.7,147.9,137.9,132.7,131.9,131.1,129.51,129.48,127.2,127.0,123.5$, 
107.6, 104.1, 25.4. HRMS (ESI/Q-TOF) $m / z:[\mathrm{M}+\mathrm{H}]^{+}$calcd for $\mathrm{C}_{21} \mathrm{H}_{17}{ }^{79} \mathrm{BrNO}_{3} 410.0386$, found 410.0388 ; calcd for $\mathrm{C}_{21} \mathrm{H}_{17}{ }^{81} \mathrm{BrNO}_{3} 412.0372$, found 412.0370 .

3-Acetoacetyl-4-(4-t-butoxyphenyl)-6-phenyl-2(1H)-pyridone (3d) was prepared from 2d according to the general procedure and was isolated by flash chromatography (DCM/EtOAc 80:20 then DCM/EtOAc/EtOH 80:15:5). $670 \mathrm{mg}$ (1.66 mmol, 83\% yield), yellowish solid (cyclohexane). Ratio enol/keto 3.8:1. ${ }^{1} \mathrm{H}$ NMR (400 MHz, $\mathrm{CDCl}_{3}$, enol form) $\delta 15.43$ (br s, $1 \mathrm{H}$ ), 12.58 (br s, $\left.1 \mathrm{H}\right), 7.87-7.80$ (m, 2H), $7.53-7.44(\mathrm{~m}, 3 \mathrm{H}), 7.34(\mathrm{dm}, J=8.6 \mathrm{~Hz}, 2 \mathrm{H}), 7.01(\mathrm{dm}, J=8.6 \mathrm{~Hz}, 2 \mathrm{H}), 6.63(\mathrm{~s}, 1 \mathrm{H}), 5.72(\mathrm{~s}, 1 \mathrm{H})$, 1.99 (s, 3H), 1.39 (s, 9H). ${ }^{1} \mathrm{H}$ NMR (400 MHz, $\mathrm{CDCl}_{3}$, keto form) $\delta 12.58$ (br s, 1H), $7.87-7.80$ (m, 2H), $7.53-7.44(\mathrm{~m}, 3 \mathrm{H}), 7.31(\mathrm{dm}, J=8.6 \mathrm{~Hz}, 2 \mathrm{H}), 7.01(\mathrm{dm}, J=8.6 \mathrm{~Hz}, 2 \mathrm{H}), 6.60(\mathrm{~s}, 1 \mathrm{H}), 3.90(\mathrm{~s}, 2 \mathrm{H}), 2.02$ (s, 3H), 1.39 (s, 9H). ${ }^{13} \mathrm{C}\left\{{ }^{1} \mathrm{H}\right\}$ NMR (101 MHz, $\mathrm{CDCl}_{3}$, enol form) $\delta 191.3,185.4,163.0,156.6,154.2$, 147.7, 133.4, 133.0, 130.8, 129.3 (2C), 128.9, 127.1, 123.8, 107.9, 104.1, 79.2, 29.0, 25.3. HRMS (ESI/QTOF) $m / z:[\mathrm{M}+\mathrm{H}]^{+}$calcd for $\mathrm{C}_{25} \mathrm{H}_{26} \mathrm{NO}_{4} 404.1862$, found 404.1859 .

3-Acetoacetyl-4-(4-morpholinophenyl)-6-phenyl-2(1H)-pyridone (3e) was prepared from $2 \mathrm{e}$ according to the general procedure and was isolated by flash chromatography (DCM/EtOAc 70:30 then DCM/EtOAc/EtOH 70:25:5). $624 \mathrm{mg}$ (1.50 mmol, 75\% yield), orange solid (cyclohexane). Ratio enol/keto 3.9:1. ${ }^{1} \mathrm{H}$ NMR (400 MHz, $\mathrm{CDCl}_{3}$, enol form) $\delta 15.49$ (br s, 1H), 12.56 (br s, 1H), $7.85-7.78$ (m, 2H), 7.52 $-7.44(\mathrm{~m}, 3 \mathrm{H}), 7.38(\mathrm{dm}, J=8.8 \mathrm{~Hz}, 2 \mathrm{H}), 6.91(\mathrm{dm}, J=8.8 \mathrm{~Hz}, 2 \mathrm{H}), 6.62(\mathrm{~s}, 1 \mathrm{H}), 5.85(\mathrm{~s}, 1 \mathrm{H}), 3.91-3.83$ $(\mathrm{m}, 4 \mathrm{H}), 3.31-3.19(\mathrm{~m}, 4 \mathrm{H}), 2.05(\mathrm{~s}, 3 \mathrm{H}) .{ }^{1} \mathrm{H}$ NMR (400 MHz, $\mathrm{CDCl}_{3}$, keto form) $\delta 12.56$ (br s, $\left.1 \mathrm{H}\right), 7.85-$ $7.78(\mathrm{~m}, 2 \mathrm{H}), 7.52-7.44(\mathrm{~m}, 3 \mathrm{H}), 7.33(\mathrm{dm}, J=8.8 \mathrm{~Hz}, 2 \mathrm{H}), 6.91(\mathrm{dm}, J=8.8 \mathrm{~Hz}, 2 \mathrm{H}), 6.59(\mathrm{~s}, 1 \mathrm{H}), 3.93$ $(\mathrm{s}, 2 \mathrm{H}), 3.91-3.83(\mathrm{~m}, 4 \mathrm{H}), 3.31-3.19(\mathrm{~m}, 4 \mathrm{H}), 2.04(\mathrm{~s}, 3 \mathrm{H}) .{ }^{13} \mathrm{C}\left\{{ }^{1} \mathrm{H}\right\} \mathrm{NMR}\left(101 \mathrm{MHz}, \mathrm{CDCl}_{3}\right.$, enol form) $\delta 191.5,185.7,163.1,154.2,151.7,147.4,133.0,130.7,129.32,129.28,129.24,127.1,122.3,114.9,107.8$, 104.2, 66.9, 48.5, 25.4. HRMS (ESI/Q-TOF) $m / z$ : $[\mathrm{M}+\mathrm{H}]^{+}$calcd for $\mathrm{C}_{25} \mathrm{H}_{25} \mathrm{~N}_{2} \mathrm{O}_{4} 417.1809$, found 417.1808 .

2-Methyl-5,7-diphenyl-4H-pyrano[2,3-b]pyridin-4-one (5a) (Scheme 3). 1,3-Diketone 3a (33 mg, $0.1 \mathrm{mmol})$ was dissolved in $\mathrm{H}_{2} \mathrm{SO}_{4}(1 \mathrm{~mL})$ and the resulting mixture was stirred $1 \mathrm{~h}$ at $\mathrm{rt}$. The reaction mixture was then diluted with chloroform $(3 \mathrm{~mL})$, cooled to $0{ }^{\circ} \mathrm{C}$, and quenched under vigorous stirring by dropwise addition of an excess volume of cold $\mathrm{H}_{2} \mathrm{O}$. The organic layer was separated and the aqueous layer was extracted again with chloroform. The combined organic layers were washed with successively $\mathrm{H}_{2} \mathrm{O}$, aq $\mathrm{NaHCO}_{3}$ and brine, then dried over $\mathrm{Na}_{2} \mathrm{SO}_{4}$ and concentrated. The product was isolated by flash chromatography on silica gel (DCM/EtOAc 97:3). $28 \mathrm{mg}$ (0.089 mmol, 89\% yield), white solid (cyclohexane). ${ }^{1} \mathrm{H}$ NMR $\left(400 \mathrm{MHz}, \mathrm{CDCl}_{3}\right) \delta 8.17-8.08(\mathrm{~m}, 2 \mathrm{H}), 7.66(\mathrm{~s}, 1 \mathrm{H}), 7.55-7.48(\mathrm{~m}, 3 \mathrm{H}), 7.48-$ $7.42(\mathrm{~m}, 3 \mathrm{H}), 7.42-7.36(\mathrm{~m}, 2 \mathrm{H}), 6.10(\mathrm{~d}, J=0.5 \mathrm{~Hz}, 1 \mathrm{H}), 2.45(\mathrm{~d}, J=0.5 \mathrm{~Hz}, 3 \mathrm{H}) .{ }^{13} \mathrm{C}\left\{{ }^{1} \mathrm{H}\right\} \mathrm{NMR}(101$ $\left.\mathrm{MHz}, \mathrm{CDCl}_{3}\right) \delta 178.3,165.1,162.2,159.1,154.6,139.1,137.0,130.8,129.1,128.41,128.38,127.9,127.8$, 121.6, 114.1, 112.3, 20.4. HRMS (ESI/Q-TOF) $m / z:[\mathrm{M}+\mathrm{H}]^{+}$calcd for $\mathrm{C}_{21} \mathrm{H}_{16} \mathrm{NO}_{2}$ 314.1181, found 314.1180 . 
General procedure for the synthesis of 2 -(methylthio)-azachromones 4 a-e (Scheme 4). To a suspension of 1,3-diketone 3 (1 mmol) in anhydrous acetonitrile $(10 \mathrm{~mL})$ under argon atmosphere, DBU $(0.33 \mathrm{~mL}, 2.2 \mathrm{mmol})$ was added and the resulting mixture was stirred $30 \mathrm{~min}$ at rt while the starting diketone dissolved. Then, carbon disulfide $(0.54 \mathrm{~mL}, 9 \mathrm{mmol})$ was first added, followed after $4 \mathrm{~h}$ by dimethyl sulfate $(0.21 \mathrm{~mL}, 2.2 \mathrm{mmol})$. The reaction mixture was stirred $12 \mathrm{~h}$ at $\mathrm{rt}$ while product 4 slowly precipitated. After completion, $10 \mathrm{~mL}$ acetonitrile and $20 \mathrm{~mL} \mathrm{H}_{2} \mathrm{O}$ were added, resulting in the complete precipitation of the product. After $15 \mathrm{~min}$ of additional stirring, the product was recovered by filtration, washed with successively $\mathrm{H}_{2} \mathrm{O}$ /acetonitrile mixture $(1: 1 \mathrm{v} / \mathrm{v})$ and petroleum ether, and dried under vacuum.

3-Acetyl-2-(methylthio)-5,7-diphenyl-4H-pyrano[2,3-b]pyridin-4-one (4a) was prepared from 3a according to the general procedure. $353 \mathrm{mg}\left(0.91 \mathrm{mmol}, 91 \%\right.$ yield), pale yellow solid. ${ }^{1} \mathrm{H} \mathrm{NMR}$ (400 MHz, $\left.\mathrm{CDCl}_{3}\right) \delta 8.17-8.11(\mathrm{~m}, 2 \mathrm{H}), 7.69(\mathrm{~s}, 1 \mathrm{H}), 7.56-7.44(\mathrm{~m}, 6 \mathrm{H}), 7.43-7.37(\mathrm{~m}, 2 \mathrm{H}), 2.71(\mathrm{~s}, 3 \mathrm{H}), 2.58(\mathrm{~s}$, $3 \mathrm{H}) .{ }^{13} \mathrm{C}\left\{{ }^{1} \mathrm{H}\right\} \mathrm{NMR}\left(101 \mathrm{MHz}, \mathrm{CDCl}_{3}\right) \delta 197.9,177.4,174.6,160.8,159.0,155.3,139.0,136.7,131.1$, 129.2, 128.7, 128.3, 128.1, 127.8, 122.6, 119.9, 114.2, 32.2, 14.6. HRMS (ESI/Q-TOF) $m / z:[\mathrm{M}+\mathrm{H}]^{+}$calcd for $\mathrm{C}_{23} \mathrm{H}_{18} \mathrm{NO}_{3} \mathrm{~S} 388.1007$, found 388.1008.

3-Acetyl-5-(4-chlorophenyl)-2-(methylthio)-7-phenyl-4H-pyrano[2,3-b]pyridin-4-one (4b) was prepared from $\mathbf{3 b}$ according to the general procedure. $367 \mathrm{mg}\left(0.87 \mathrm{mmol}, 87 \%\right.$ yield), pale yellow solid. ${ }^{1} \mathrm{H}$ NMR (400 MHz, $\left.\mathrm{CDCl}_{3}\right) \delta 8.19-8.08(\mathrm{~m}, 2 \mathrm{H}), 7.65(\mathrm{~s}, 1 \mathrm{H}), 7.58-7.49(\mathrm{~m}, 3 \mathrm{H}), 7.45(\mathrm{dm}, J=8.5 \mathrm{~Hz}$, $2 \mathrm{H}), 7.34(\mathrm{dm}, J=8.5 \mathrm{~Hz}, 2 \mathrm{H}), 2.71(\mathrm{~s}, 3 \mathrm{H}), 2.58(\mathrm{~s}, 3 \mathrm{H}) .{ }^{13} \mathrm{C}\left\{{ }^{1} \mathrm{H}\right\} \mathrm{NMR}\left(101 \mathrm{MHz}, \mathrm{CDCl}_{3}\right) \delta 197.8,177.6$, 174.6, 160.8, 159.3, 154.0, 137.4, 136.6, 134.9, 131.2, 129.7, 129.3, 128.5, 127.8, 122.4, 119.8, 114.1, 32.2, 14.6. HRMS (ESI/Q-TOF) $m / z:[\mathrm{M}+\mathrm{H}]^{+}$calcd for $\mathrm{C}_{23} \mathrm{H}_{17} \mathrm{ClNO}_{3} \mathrm{~S} 422.0612$, found 422.0619 .

3-Acetyl-5-(4-bromophenyl)-2-(methylthio)-7-phenyl-4H-pyrano[2,3-b]pyridin-4-one (4c) was prepared from $3 \mathbf{c}$ according to the general procedure. $410 \mathrm{mg}(0.88 \mathrm{mmol}, 88 \%$ yield $)$, pale yellow solid. ${ }^{1} \mathrm{H}$ NMR (400 MHz, $\left.\mathrm{CDCl}_{3}\right) \delta 8.16-8.09(\mathrm{~m}, 2 \mathrm{H}), 7.65(\mathrm{~s}, 1 \mathrm{H}), 7.60(\mathrm{dm}, J=8.5 \mathrm{~Hz}, 2 \mathrm{H}), 7.55-7.50(\mathrm{~m}$, $3 \mathrm{H}), 7.28(\mathrm{dm}, J=8.5 \mathrm{~Hz}, 2 \mathrm{H}), 2.71(\mathrm{~s}, 3 \mathrm{H}), 2.57(\mathrm{~s}, 3 \mathrm{H}) .{ }^{13} \mathrm{C}\left\{{ }^{1} \mathrm{H}\right\} \mathrm{NMR}\left(101 \mathrm{MHz}, \mathrm{CDCl}_{3}\right) \delta 197.7,177.6$, 174.5, 160.8, 159.3, 154.0, 137.9, 136.5, 131.4, 131.2, 130.0, 129.2, 127.8, 123.1, 122.3, 119.8, 114.0, 32.2, 14.6. HRMS (ESI/Q-TOF) $\mathrm{m} / z$ : $[\mathrm{M}+\mathrm{H}]^{+}$calcd for $\mathrm{C}_{23} \mathrm{H}_{17}{ }^{79} \mathrm{BrNO}_{3} \mathrm{~S} 466.0107$, found 466.0119 ; calcd for $\mathrm{C}_{23} \mathrm{H}_{17}{ }^{81} \mathrm{BrNO}_{3} \mathrm{~S} 468.0092$, found 468.0103 .

3-Acetyl-5-(4-t-butoxyphenyl)-2-(methylthio)-7-phenyl-4H-pyrano[2,3-b]pyridin-4-one (4d) was prepared from 3d according to the general procedure. $409 \mathrm{mg}\left(0.89 \mathrm{mmol}, 89 \%\right.$ yield), pale yellow solid. ${ }^{1} \mathrm{H}$ NMR (400 MHz, $\left.\mathrm{CDCl}_{3}\right) \delta 8.18-8.10(\mathrm{~m}, 2 \mathrm{H}), 7.70(\mathrm{~s}, 1 \mathrm{H}), 7.56-7.48(\mathrm{~m}, 3 \mathrm{H}), 7.33(\mathrm{dm}, J=8.6 \mathrm{~Hz}$, $2 \mathrm{H}), 7.08(\mathrm{dm}, J=8.6 \mathrm{~Hz}, 2 \mathrm{H}), 2.71(\mathrm{~s}, 3 \mathrm{H}), 2.59(\mathrm{~s}, 3 \mathrm{H}), 1.45(\mathrm{~s}, 9 \mathrm{H}) .{ }^{13} \mathrm{C}\left\{{ }^{1} \mathrm{H}\right\} \mathrm{NMR}\left(101 \mathrm{MHz}, \mathrm{CDCl}_{3}\right) \delta$ $197.9,177.1,174.7,160.9,158.9,156.4,155.1,136.8,133.2,131.0,129.4,129.2,127.8,123.0,122.7$, 119.9, 114.2, 79.0, 32.1, 29.1, 14.6. HRMS (ESI/Q-TOF) $\mathrm{m} / \mathrm{z}:[\mathrm{M}+\mathrm{H}]^{+}$calcd for $\mathrm{C}_{27} \mathrm{H}_{26} \mathrm{NO}_{4} \mathrm{~S} 460.1577$, found 460.1591 . 
was prepared from 3e according to the general procedure. $421 \mathrm{mg}(0.89 \mathrm{mmol}, 89 \%$ yield $)$, yellowish solid. ${ }^{1} \mathrm{H}$ NMR $\left(400 \mathrm{MHz}, \mathrm{CDCl}_{3}\right) \delta 8.16-8.08(\mathrm{~m}, 2 \mathrm{H}), 7.69(\mathrm{~s}, 1 \mathrm{H}), 7.57-7.47(\mathrm{~m}, 3 \mathrm{H}), 7.38(\mathrm{dm}, J=8.7 \mathrm{~Hz}$, 2H), $6.98(\mathrm{dm}, J=8.7 \mathrm{~Hz}, 2 \mathrm{H}), 3.95-3.82(\mathrm{~m}, 4 \mathrm{H}), 3.36-3.21(\mathrm{~m}, 4 \mathrm{H}), 2.71(\mathrm{~s}, 3 \mathrm{H}), 2.61$ (s, 3H). ${ }^{13} \mathrm{C}\left\{{ }^{1} \mathrm{H}\right\} \mathrm{NMR}\left(101 \mathrm{MHz}, \mathrm{CDCl}_{3}\right) \delta 198.0,177.1,175.0,161.1,158.8,155.1,151.5,136.9,130.9,130.0$, 129.3, 129.2, 127.7, 122.5, 119.9, 114.4, 114.0, 67.0, 48.5, 32.3, 14.6. HRMS (ESI/Q-TOF) $m / z:[\mathrm{M}+\mathrm{H}]^{+}$ calcd for $\mathrm{C}_{27} \mathrm{H}_{25} \mathrm{~N}_{2} \mathrm{O}_{4} \mathrm{~S} 473.1530$, found 473.1528 .

General procedures for the synthesis of 2-(substituted amino)-8-azachromones 6aa-am, 6ba-bc, 6ca-cc, 6da-db and 6ea-eb (Table 2 and Scheme 7). Note: safety precautions must be taken due to the release of toxic methanethiol. Procedure A: 2-(Methylthio)-8-azachromone 4 (0.1 mmol) and amine (amount indicated) were dissolved in anhydrous DCM (volume indicated) under argon atmosphere, and the resulting mixture was stirred under the indicated conditions. After completion, the crude reaction mixture was applied on top of a silica gel column and the product was eluted with the indicated solvent. Procedure B: 2-(Methylthio)-8-azachromone $4(0.1 \mathrm{mmol})$, amine $(0.11 \mathrm{mmol})$ and DMAP $(4 \mathrm{mg}, 0.03 \mathrm{mmol})$ were dissolved in the indicated anhydrous solvent (THF or 1,4-dioxane, $2 \mathrm{~mL}$ ), and the resulting mixture was stirred in open air under the indicated conditions. After completion, the reaction mixture was cooled to $\mathrm{rt}$ and the product was precipitated by addition of the indicated solvents. After 15 min of additional stirring, the product was recovered by filtration, washed with the indicated solvents, and dried under vacuum.

3-Acetyl-5,7-diphenyl-2-(piperidin-1-yl)-4H-pyrano[2,3-b]pyridin-4-one (6aa) was prepared from 4a and piperidine $(11 \mu \mathrm{L}, 0.11 \mathrm{mmol})$ according to procedure A ( $1 \mathrm{~mL} \mathrm{DCM}, \mathrm{rt}, 12 \mathrm{~h})$, and was eluted with DCM/EtOAc 85:15. $41 \mathrm{mg}\left(0.096 \mathrm{mmol}, 96 \%\right.$ yield), white solid (cyclohexane). ${ }^{1} \mathrm{H}$ NMR (400 MHz, $\left.\mathrm{CDCl}_{3}\right) \delta 8.11-8.06(\mathrm{~m}, 2 \mathrm{H}), 7.57(\mathrm{~s}, 1 \mathrm{H}), 7.54-7.37(\mathrm{~m}, 8 \mathrm{H}), 3.56-3.49(\mathrm{~m}, 4 \mathrm{H}), 2.54(\mathrm{~s}, 3 \mathrm{H}), 1.83-$ $1.70(\mathrm{~m}, 6 \mathrm{H}) .{ }^{13} \mathrm{C}\left\{{ }^{1} \mathrm{H}\right\} \mathrm{NMR}\left(101 \mathrm{MHz}, \mathrm{CDCl}_{3}\right) \delta 197.9,176.7,163.3,158.5,158.2,154.6,139.8,137.3$, 130.5, 129.1, 128.34, 128.29, 127.9, 127.6, 121.8, 114.0, 103.8, 50.3, 33.0, 26.0, 23.9. HRMS (ESI/Q-TOF) $m / z:[\mathrm{M}+\mathrm{H}]^{+}$calcd for $\mathrm{C}_{27} \mathrm{H}_{25} \mathrm{~N}_{2} \mathrm{O}_{3} 425.1860$, found 425.1877 .

3-Acetyl-2-morpholino-5,7-diphenyl-4H-pyrano[2,3-b]pyridin-4-one (6ab) was prepared from 4a and morpholine $(10 \mu \mathrm{L}, 0.11 \mathrm{mmol})$ according to procedure $\mathrm{A}(1 \mathrm{~mL} \mathrm{DCM}, \mathrm{rt}, 12 \mathrm{~h})$, and was eluted with DCM/EtOAc 4:1. $40 \mathrm{mg}$ (0.093 mmol, 93\% yield), white solid (cyclohexane). ${ }^{1} \mathrm{H}$ NMR (400 MHz, $\left.\mathrm{CDCl}_{3}\right)$ $\delta 8.15-8.01(\mathrm{~m}, 2 \mathrm{H}), 7.60(\mathrm{~s}, 1 \mathrm{H}), 7.54-7.37(\mathrm{~m}, 8 \mathrm{H}), 3.93-3.82(\mathrm{~m}, 4 \mathrm{H}), 3.65-3.54(\mathrm{~m}, 4 \mathrm{H}), 2.54(\mathrm{~s}$, $3 \mathrm{H}) .{ }^{13} \mathrm{C}\left\{{ }^{1} \mathrm{H}\right\} \mathrm{NMR}\left(101 \mathrm{MHz}, \mathrm{CDCl}_{3}\right) \delta 197.9,176.8,163.0,158.4$ (2C), 154.7, 139.5, 137.1, 130.6, 129.1, 128.4, 128.3, 128.0, 127.6, 122.0, 113.9, 104.1, 66.5, 49.3, 33.1. HRMS (ESI/Q-TOF) $m / z:[\mathrm{M}+\mathrm{H}]^{+}$calcd for $\mathrm{C}_{26} \mathrm{H}_{23} \mathrm{~N}_{2} \mathrm{O}_{4} 427.1652$, found 427.1665 .

3-Acetyl-2-(methylamino)-5,7-diphenyl-4H-pyrano[2,3-b]pyridin-4-one (6ac) was prepared from 4a and methylamine (8.03 M solution in absolute ethanol, $14 \mu \mathrm{L}, 0.11 \mathrm{mmol}$ ) according to procedure A (1 mL DCM, rt, $12 \mathrm{~h}$ ), and was eluted with DCM/EtOAc 19:1. $36 \mathrm{mg}$ (0.097 mmol, 97\% yield), white solid 
(cyclohexane). ${ }^{1} \mathrm{H}$ NMR (400 MHz, $\left.\mathrm{CDCl}_{3}\right) \delta 11.49$ (br q, 1H), $8.16-8.04(\mathrm{~m}, 2 \mathrm{H}), 7.61$ (s, 1H), $7.55-$ $7.43(\mathrm{~m}, 6 \mathrm{H}), 7.42-7.35(\mathrm{~m}, 2 \mathrm{H}), 3.31(\mathrm{~d}, J=5.1 \mathrm{~Hz}, 3 \mathrm{H}), 2.59(\mathrm{~s}, 3 \mathrm{H}) .{ }^{13} \mathrm{C}\left\{{ }^{1} \mathrm{H}\right\}$ NMR $\left(101 \mathrm{MHz}, \mathrm{CDCl}_{3}\right)$ $\delta 199.8,175.3,165.8,158.03,157.97,155.2,139.9,137.0,130.7,129.1,128.3,128.2,128.0,127.6,122.4$, 114.0, 100.2, 32.6, 28.0. HRMS (ESI/Q-TOF) $m / z:[\mathrm{M}+\mathrm{H}]^{+}$calcd for $\mathrm{C}_{23} \mathrm{H}_{19} \mathrm{~N}_{2} \mathrm{O}_{3}$ 371.1390, found 371.1409 .

3-Acetyl-2-(benzylamino)-5,7-diphenyl-4H-pyrano[2,3-b]pyridin-4-one (6ad) was prepared from 4a and benzylamine $(12 \mu \mathrm{L}, 0.11 \mathrm{mmol})$ according to procedure A (1 mL DCM, rt, $12 \mathrm{~h})$, and was eluted with DCM/EtOAc 19:1. $42 \mathrm{mg}$ (0.094 mmol, 94\% yield), white solid (cyclohexane). ${ }^{1} \mathrm{H}$ NMR (400 MHz, $\left.\mathrm{CDCl}_{3}\right) \delta 11.91($ br t, $J=5.4 \mathrm{~Hz}, 1 \mathrm{H}), 8.17-8.05(\mathrm{~m}, 2 \mathrm{H}), 7.61(\mathrm{~s}, 1 \mathrm{H}), 7.55-7.37(\mathrm{~m}, 12 \mathrm{H}), 7.37-7.32$ $(\mathrm{m}, 1 \mathrm{H}), 4.91(\mathrm{~d}, J=5.8 \mathrm{~Hz}, 2 \mathrm{H}), 2.60(\mathrm{~s}, 3 \mathrm{H}) .{ }^{13} \mathrm{C}\left\{{ }^{1} \mathrm{H}\right\} \mathrm{NMR}\left(101 \mathrm{MHz}, \mathrm{CDCl}_{3}\right) \delta 199.8,175.4,164.9$, 158.0 , 157.9, 155.1, 139.9, 137.0, 136.3, 130.7, 129.16, 129.13, 128.3, 128.23, 128.19, 127.98, 127.95, 127.6, 122.4, 114.0, 100.1, 45.5, 32.7. HRMS (ESI/Q-TOF) $m / z:[\mathrm{M}+\mathrm{H}]^{+}$calcd for $\mathrm{C}_{29} \mathrm{H}_{23} \mathrm{~N}_{2} \mathrm{O}_{3} 447.1709$, found 447.1710 .

3-Acetyl-2-(2-hydroxyethylamino)-5,7-diphenyl-4H-pyrano[2,3-b]pyridin-4-one (6ae) was prepared from $4 \mathbf{a}$ and ethanolamine $(7 \mu \mathrm{L}, 0.11 \mathrm{mmol})$ according to procedure A ( $1 \mathrm{~mL}$ DCM, rt, $12 \mathrm{~h})$. After completion, the precipitated product was recovered by filtration and washed with DCM. 26 mg (0.065 mmol, 65\% yield), white solid. ${ }^{1} \mathrm{H}$ NMR (400 MHz, DMSO-d 6 ) $\delta 11.40$ (br t, 1H), $8.25-8.19$ (m, 2H), 7.80 (s, 1H), $7.58-7.50(\mathrm{~m}, 3 \mathrm{H}), 7.42(\mathrm{br} \mathrm{s}, 5 \mathrm{H}), 5.13(\mathrm{t}, J=4.6 \mathrm{~Hz}, 1 \mathrm{H}), 3.76-3.66(\mathrm{~m}, 4 \mathrm{H}), 2.41(\mathrm{~s}, 3 \mathrm{H})$. ${ }^{13} \mathrm{C}\left\{{ }^{1} \mathrm{H}\right\}$ NMR (101 MHz, DMSO-d $d_{6} \delta 197.4,174.7,164.4,157.5,156.7,154.2,139.6,136.2,130.8,129.1$, 128.5, 127.8, 127.54, 127.45, 121.6, 113.5, 99.3, 59.2, 43.5, 32.1. HRMS (ESI/Q-TOF) $\mathrm{m} / \mathrm{z}:[\mathrm{M}+\mathrm{H}]^{+}$calcd for $\mathrm{C}_{24} \mathrm{H}_{21} \mathrm{~N}_{2} \mathrm{O}_{4} 401.1501$, found 401.1498 .

Methyl 2-(3-acetyl-4-oxo-5,7-diphenyl-4H-pyrano[2,3-b]pyridin-2-ylamino)acetate (6af) was prepared from $4 \mathbf{a}$ according to procedure A (1 mL DCM, rt, $12 \mathrm{~h})$ using glycine methyl ester hydrochloride (19 $\mathrm{mg}, 0.15 \mathrm{mmol})$ and triethylamine $(15 \mu \mathrm{L}, 0.11 \mathrm{mmol})$, and was eluted with DCM/EtOAc 9:1. $27 \mathrm{mg}$ (0.063 mmol, 63\% yield), white solid (cyclohexane). ${ }^{1} \mathrm{H} \mathrm{NMR}\left(400 \mathrm{MHz}, \mathrm{CDCl}_{3}\right) \delta 11.88$ (br t, $J=5.3 \mathrm{~Hz}$, $1 \mathrm{H}), 8.12-8.05(\mathrm{~m}, 2 \mathrm{H}), 7.61(\mathrm{~s}, 1 \mathrm{H}), 7.55-7.43(\mathrm{~m}, 6 \mathrm{H}), 7.42-7.35(\mathrm{~m}, 2 \mathrm{H}), 4.51(\mathrm{~d}, J=5.6 \mathrm{~Hz}, 2 \mathrm{H})$, $3.87(\mathrm{~s}, 3 \mathrm{H}), 2.62(\mathrm{~s}, 3 \mathrm{H}) .{ }^{13} \mathrm{C}\left\{{ }^{1} \mathrm{H}\right\} \mathrm{NMR}\left(101 \mathrm{MHz}, \mathrm{CDCl}_{3}\right) \delta 200.0,175.3,168.7,165.2,158.2,157.8$, 155.2, 139.7, 136.9, 130.8, 129.2, 128.4, 128.2, 128.0, 127.6, 122.5, 114.1, 100.4, 53.0, 43.0, 32.6. HRMS (ESI/Q-TOF) $m / z:[\mathrm{M}+\mathrm{H}]^{+}$calcd for $\mathrm{C}_{25} \mathrm{H}_{21} \mathrm{~N}_{2} \mathrm{O}_{5} 429.1445$, found 429.1437 .

\section{3-Acetyl-2-(4-methoxyphenylamino)-5,7-diphenyl-4H-pyrano[2,3-b]pyridin-4-one (6ag) was} prepared from $4 \mathbf{a}$ and $p$-anisidine according to procedure $\mathrm{B}\left(2 \mathrm{~mL} \mathrm{THF}, 65^{\circ} \mathrm{C}, 2 \mathrm{~h}\right)$. The product was precipitated by addition of cyclohexane $(4 \mathrm{~mL})$, recovered by filtration, and washed with cyclohexane/THF 2:1 and petroleum ether. $42 \mathrm{mg}\left(0.091 \mathrm{mmol}, 91 \%\right.$ yield), white solid. ${ }^{1} \mathrm{H}$ NMR (400 MHz, $\left.\mathrm{CDCl}_{3}\right) \delta 13.49$ (s, 1H), $8.13-8.06(\mathrm{~m}, 2 \mathrm{H}), 7.63(\mathrm{~s}, 1 \mathrm{H}), 7.53(\mathrm{dm}, J=9.0 \mathrm{~Hz}, 2 \mathrm{H}), 7.51-7.45(\mathrm{~m}, 6 \mathrm{H}), 7.44-7.38(\mathrm{~m}$, 2H), $7.02(\mathrm{dm}, J=9.0 \mathrm{~Hz}, 2 \mathrm{H}), 3.88(\mathrm{~s}, 3 \mathrm{H}), 2.67(\mathrm{~s}, 3 \mathrm{H}) .{ }^{13} \mathrm{C}\left\{{ }^{1} \mathrm{H}\right\} \mathrm{NMR}\left(101 \mathrm{MHz}, \mathrm{CDCl}_{3}\right) \delta 200.1,175.5$, 
162.6, 158.2, 158.1, 157.9, 155.0, 139.8, 136.8, 130.8, 129.1, 128.40, 128.36, 128.2, 128.0, 127.6, 124.8, 122.3, 114.8, 114.1, 100.1, 55.7, 32.8. HRMS (ESI/Q-TOF) $m / z:[\mathrm{M}+\mathrm{H}]^{+}$calcd for $\mathrm{C}_{29} \mathrm{H}_{23} \mathrm{~N}_{2} \mathrm{O}_{4} 463.1652$, found 463.1643 .

3-Acetyl-5,7-diphenyl-2-(phenylamino)-4H-pyrano[2,3-b]pyridin-4-one (6ah) was prepared from 4a and aniline according to procedure $\mathrm{B}\left(2 \mathrm{~mL} \mathrm{THF}, 65^{\circ} \mathrm{C}, 2 \mathrm{~h}\right)$. The product was precipitated by addition of cyclohexane $(4 \mathrm{~mL})$, recovered by filtration, and washed with cyclohexane/THF 2:1 and petroleum ether. $39 \mathrm{mg}$ (0.09 mmol, 90\% yield), pale yellow solid. ${ }^{1} \mathrm{H}$ NMR (400 MHz, $\left.\mathrm{CDCl}_{3}\right) \delta 13.61$ (s, $\left.1 \mathrm{H}\right), 8.15-8.08$ $(\mathrm{m}, 2 \mathrm{H}), 7.67-7.61(\mathrm{~m}, 2 \mathrm{H}), 7.64(\mathrm{~s}, 1 \mathrm{H}), 7.54-7.46(\mathrm{~m}, 8 \mathrm{H}), 7.44-7.38(\mathrm{~m}, 2 \mathrm{H}), 7.32(\mathrm{tm}, J=7.4 \mathrm{~Hz}$, 1H), $2.68(\mathrm{~s}, 3 \mathrm{H}) .{ }^{13} \mathrm{C}\left\{{ }^{1} \mathrm{H}\right\} \mathrm{NMR}\left(101 \mathrm{MHz}, \mathrm{CDCl}_{3}\right) \delta 200.3,175.6,162.8,158.3,157.9,155.0,139.7$, 136.8, 135.8, 130.8, 129.7, 129.1, 128.4, 128.2, 128.0, 127.7, 126.4, 123.2, 122.4, 114.2, 100.3, 32.8. HRMS (ESI/Q-TOF) $m / z:[\mathrm{M}+\mathrm{H}]^{+}$calcd for $\mathrm{C}_{28} \mathrm{H}_{21} \mathrm{~N}_{2} \mathrm{O}_{3} 433.1547$, found 433.1551.

Ethyl 4-(3-acetyl-4-oxo-5,7-diphenyl-4H-pyrano[2,3-b]pyridin-2-ylamino)benzoate (6ai) was prepared from 4a and ethyl 4-aminobenzoate according to procedure $\mathrm{B}\left(2 \mathrm{~mL}\right.$ dioxane, $\left.100{ }^{\circ} \mathrm{C}, 36 \mathrm{~h}\right)$. The product was precipitated by addition of dioxane $(2 \mathrm{~mL})$ and cyclohexane $(8 \mathrm{~mL})$, recovered by filtration, and washed with cyclohexane/dioxane $2: 1$ and petroleum ether. $31 \mathrm{mg}(0.061 \mathrm{mmol}, 61 \%$ yield $)$, white solid. ${ }^{1} \mathrm{H}$ $\operatorname{NMR}\left(400 \mathrm{MHz}, \mathrm{CDCl}_{3}\right) \delta 13.80(\mathrm{~s}, 1 \mathrm{H}), 8.18(\mathrm{dm}, J=8.7 \mathrm{~Hz}, 2 \mathrm{H}), 8.16-8.11(\mathrm{~m}, 2 \mathrm{H}), 7.74(\mathrm{dm}, J=8.7$ $\mathrm{Hz}, 2 \mathrm{H}), 7.67$ (s, 1H), $7.56-7.45(\mathrm{~m}, 6 \mathrm{H}), 7.44-7.38(\mathrm{~m}, 2 \mathrm{H}), 4.42$ (q, J= 7.1 Hz, 2H), 2.69 (s, 3H), 1.43 $(\mathrm{t}, J=7.1 \mathrm{~Hz}, 3 \mathrm{H}) .{ }^{13} \mathrm{C}\left\{{ }^{1} \mathrm{H}\right\} \mathrm{NMR}\left(101 \mathrm{MHz}, \mathrm{CDCl}_{3}\right) \delta 200.7,175.5,166.0,162.7,158.5,157.8,155.1$, 139.8, 139.5, 136.6, 131.3, 131.0, 129.2, 128.5, 128.2, 128.1, 127.8, 127.7, 122.5, 122.3, 114.1, 100.7, 61.3, 32.8, 14.5. HRMS (ESI/Q-TOF) $m / z:[\mathrm{M}+\mathrm{H}]^{+}$calcd for $\mathrm{C}_{31} \mathrm{H}_{25} \mathrm{~N}_{2} \mathrm{O}_{5} 505.1758$, found 505.1732 .

(S)-Methyl

2-(3-acetyl-4-oxo-5,7-diphenyl-4H-pyrano[2,3-b]pyridin-2-ylamino)-3-

phenylpropanoate (6aj) was prepared from 4a according to procedure A ( $1 \mathrm{~mL}$ DCM, rt, $84 \mathrm{~h})$ using Lphenylalanine methyl ester hydrochloride (32 mg, $0.15 \mathrm{mmol})$ and triethylamine (15 $\mu \mathrm{L}, 0.11 \mathrm{mmol})$, and was eluted with DCM/EtOAc 49:1. $37 \mathrm{mg}(0.071 \mathrm{mmol}, 71 \%$ yield $)$, white solid $(\mathrm{MeOH}) .[\alpha]_{\mathrm{D}}^{20}+13.2^{\circ}(c$ 1.0, $\left.\mathrm{CHCl}_{3}\right) .{ }^{1} \mathrm{H} \mathrm{NMR}\left(500 \mathrm{MHz}, \mathrm{CDCl}_{3}\right) \delta 11.91(\mathrm{~d}, J=7.8 \mathrm{~Hz}, 1 \mathrm{H}), 8.11-8.05(\mathrm{~m}, 2 \mathrm{H}), 7.58(\mathrm{~s}, 1 \mathrm{H})$, $7.55-7.42(\mathrm{~m}, 6 \mathrm{H}), 7.39-7.28(\mathrm{~m}, 6 \mathrm{H}), 7.25-7.20(\mathrm{~m}, 1 \mathrm{H}), 5.21(\mathrm{td}, J=8.0,5.0 \mathrm{~Hz}, 1 \mathrm{H}), 3.83(\mathrm{~s}, 3 \mathrm{H})$, $3.41(\mathrm{dd}, J=13.9,5.0 \mathrm{~Hz}, 1 \mathrm{H}), 3.24(\mathrm{dd}, J=13.9,8.1 \mathrm{~Hz}, 1 \mathrm{H}), 2.58(\mathrm{~s}, 3 \mathrm{H}) .{ }^{13} \mathrm{C}\left\{{ }^{1} \mathrm{H}\right\} \mathrm{NMR}(126 \mathrm{MHz}$, $\left.\mathrm{CDCl}_{3}\right) \delta 199.8,175.3,170.6,164.6,157.9,157.6,155.0,139.7,136.9,135.4,130.7,129.5,129.1,129.0$, 128.3, 128.2, 128.0, 127.60, 127.55, 122.3, 113.9, 100.2, 56.0, 53.1, 39.0, 32.7. HRMS (ESI/Q-TOF) $m / z$ : $[\mathrm{M}+\mathrm{H}]^{+}$calcd for $\mathrm{C}_{32} \mathrm{H}_{27} \mathrm{~N}_{2} \mathrm{O}_{5} 519.1914$, found 519.1915 .

(S)-Methyl

2-(3-acetyl-4-oxo-5,7-diphenyl-4H-pyrano[2,3-b]pyridin-2-ylamino)-3-(4hydroxyphenyl)propanoate (6ak) was prepared from 4a according to procedure A (1 mL DCM, rt, $84 \mathrm{~h}$ ) using L-tyrosine methyl ester hydrochloride (35 mg, $0.15 \mathrm{mmol})$ and triethylamine (15 $\mu \mathrm{L}, 0.11 \mathrm{mmol})$, and was eluted with DCM/EtOAc 85:15. $40 \mathrm{mg}\left(0.075 \mathrm{mmol}, 75 \%\right.$ yield), white solid (cyclohexane). $[\alpha]_{\mathrm{D}}^{20}$ $+29.8^{\circ}\left(c\right.$ 1.0, $\left.\mathrm{CHCl}_{3}\right) .{ }^{1} \mathrm{H}$ NMR $\left(400 \mathrm{MHz}, \mathrm{CDCl}_{3}\right) \delta 11.80(\mathrm{~d}, J=7.8 \mathrm{~Hz}, 1 \mathrm{H}), 8.12-8.03(\mathrm{~m}, 2 \mathrm{H}), 7.59$ 
(s, 1H), $7.54-7.48(\mathrm{~m}, 3 \mathrm{H}), 7.47-7.41(\mathrm{~m}, 3 \mathrm{H}), 7.39-7.33(\mathrm{~m}, 2 \mathrm{H}), 7.11(\mathrm{dm}, J=8.5 \mathrm{~Hz}, 2 \mathrm{H}), 6.72(\mathrm{dm}$, $J=8.5 \mathrm{~Hz}, 2 \mathrm{H}), 5.93(\mathrm{br} \mathrm{s}, 1 \mathrm{H}), 5.17(\mathrm{td}, J=7.7,4.9 \mathrm{~Hz}, 1 \mathrm{H}), 3.82(\mathrm{~s}, 3 \mathrm{H}), 3.31$ (dd, $J=14.1,4.9 \mathrm{~Hz}, 1 \mathrm{H})$,

$3.18(\mathrm{dd}, J=14.1,7.7 \mathrm{~Hz}, 1 \mathrm{H}), 2.58(\mathrm{~s}, 3 \mathrm{H}) .{ }^{13} \mathrm{C}\left\{{ }^{1} \mathrm{H}\right\} \mathrm{NMR}\left(101 \mathrm{MHz}, \mathrm{CDCl}_{3}\right) \delta 200.2,175.4,170.7,164.6$, $158.1,157.7,155.6,155.1,139.7,136.9$, 130.8, 130.7, 129.2, 128.4, 128.2, 128.0, 127.6, 126.8, 122.5, 115.9, 113.9, 100.3, 56.2, 53.1, 38.0, 32.5. HRMS (ESI/Q-TOF) $m / z:[\mathrm{M}+\mathrm{H}]^{+}$calcd for $\mathrm{C}_{32} \mathrm{H}_{27} \mathrm{~N}_{2} \mathrm{O}_{6}$ 535.1864, found 535.1864 .

\section{(S)-Methyl 2-(3-acetyl-4-oxo-5,7-diphenyl-4H-pyrano[2,3-b]pyridin-2-ylamino)-3-(1H-indol-3-}

yl)propanoate (6al) was prepared from 4a according to procedure A (1 mL DCM, rt, $60 \mathrm{~h})$ using Ltryptophan methyl ester hydrochloride $(38 \mathrm{mg}, 0.15 \mathrm{mmol})$ and triethylamine $(15 \mu \mathrm{L}, 0.11 \mathrm{mmol})$, and was eluted with DCM/EtOAc 9:1. $45 \mathrm{mg}(0.081 \mathrm{mmol}, 81 \%$ yield $)$, pale yellow solid $(\mathrm{MeOH}) .[\alpha]_{\mathrm{D}}^{20}-19.8^{\circ}(c$ 1.0, $\mathrm{CHCl}_{3}$ ). ${ }^{1} \mathrm{H} \mathrm{NMR}\left(400 \mathrm{MHz}, \mathrm{CDCl}_{3}\right) \delta 11.88$ (d, J=7.5 Hz, 1H), 8.20 (br s, 1H), $8.11-8.04$ (m, 2H), $7.71-7.67(\mathrm{~m}, 1 \mathrm{H}), 7.57$ (s, 1H), $7.54-7.48(\mathrm{~m}, 3 \mathrm{H}), 7.48-7.42(\mathrm{~m}, 3 \mathrm{H}), 7.38-7.33(\mathrm{~m}, 2 \mathrm{H}), 7.33-7.29$ (m, 1H), 7.23 (br d, $J=2.4 \mathrm{~Hz}, 1 \mathrm{H}), 7.20-7.12(\mathrm{~m}, 2 \mathrm{H}), 5.26(\mathrm{td}, J=7.3,5.2 \mathrm{~Hz}, 1 \mathrm{H}), 3.78(\mathrm{~s}, 3 \mathrm{H}), 3.55$ $(\mathrm{dd}, J=14.8,5.2 \mathrm{~Hz}, 1 \mathrm{H}), 3.49(\mathrm{dd}, J=14.8,7.2 \mathrm{~Hz}, 1 \mathrm{H}), 2.57(\mathrm{~s}, 3 \mathrm{H}) .{ }^{13} \mathrm{C}\left\{{ }^{1} \mathrm{H}\right\} \mathrm{NMR}\left(101 \mathrm{MHz}, \mathrm{CDCl}_{3}\right) \delta$ $199.8,175.4,171.1,164.7,157.9,157.7,155.0,139.8,136.9,136.4,130.7,129.1,128.3,128.2,128.0$, $127.6,127.1,123.7,122.5,122.2,119.9,118.7,113.9,111.5,109.4,100.3,55.3,53.1,32.6$, 28.9. HRMS (ESI/Q-TOF) $m / z:[\mathrm{M}+\mathrm{H}]^{+}$calcd for $\mathrm{C}_{34} \mathrm{H}_{28} \mathrm{~N}_{3} \mathrm{O}_{5}$ 558.2023, found 558.2017.

\section{(S)-Methyl 2-(3-acetyl-4-oxo-5,7-diphenyl-4H-pyrano[2,3-b]pyridin-2-ylamino)-3-(1H-imidazol-}

4-yl)propanoate (6am) was prepared from 4a according to procedure A (1 mL DCM, rt, $72 \mathrm{~h})$ using Lhistidine methyl ester dihydrochloride $(29 \mathrm{mg}, 0.12 \mathrm{mmol})$ and triethylamine $(28 \mu \mathrm{L}, 0.2 \mathrm{mmol})$, and was eluted with DCM/EtOH 93:7. $22 \mathrm{mg}(0.043 \mathrm{mmol}, 43 \%$ yield $)$, yellowish solid $\left(\mathrm{Et}_{2} \mathrm{O}\right)$. $[\alpha]_{\mathrm{D}}^{20}-3.4^{\circ}(c 0.5$, $\left.\mathrm{CHCl}_{3}\right) .{ }^{1} \mathrm{H}$ NMR $\left(400 \mathrm{MHz}, \mathrm{CDCl}_{3}\right) \delta 11.85(\mathrm{~d}, J=7.6 \mathrm{~Hz}, 1 \mathrm{H}), 8.09-8.03(\mathrm{~m}, 2 \mathrm{H}), 7.56-7.53(\mathrm{~m}, 2 \mathrm{H})$, $7.52-7.34(\mathrm{~m}, 9 \mathrm{H}), 6.93(\mathrm{~s}, 1 \mathrm{H}), 5.30-5.22(\mathrm{~m}, 1 \mathrm{H}), 3.84(\mathrm{~s}, 3 \mathrm{H}), 3.38(\mathrm{dd}, J=15.0,5.9 \mathrm{~Hz}, 1 \mathrm{H}), 3.30$ $(\mathrm{dd}, J=15.0,4.9 \mathrm{~Hz}, 1 \mathrm{H}), 2.55(\mathrm{~s}, 3 \mathrm{H}) .{ }^{13} \mathrm{C}\left\{{ }^{1} \mathrm{H}\right\} \mathrm{NMR}\left(151 \mathrm{MHz}, \mathrm{CDCl}_{3}\right) \delta 199.8,175.5,170.7,164.6$, 158.1, 157.8, 155.1, 139.7, 136.8, 135.6, 130.8, 129.1, 128.4 (2C), 128.2 (2C), 128.0, 127.6, 122.4, 113.9, 100.4, 54.6, 53.2, 32.6, 30.5. HRMS (ESI/Q-TOF) $m / z:[\mathrm{M}+\mathrm{H}]^{+}$calcd for $\mathrm{C}_{29} \mathrm{H}_{25} \mathrm{~N}_{4} \mathrm{O}_{5} 509.1819$, found 509.1825 .

\section{3-Acetyl-2-(benzylamino)-5-(4-chlorophenyl)-7-phenyl-4H-pyrano[2,3-b]pyridin-4-one}

(6ba)

was prepared from $\mathbf{4 b}$ and benzylamine $(12 \mu \mathrm{L}, 0.11 \mathrm{mmol})$ according to procedure A ( $2 \mathrm{~mL} \mathrm{DCM}, \mathrm{rt}, 24$ h), and was eluted with DCM/EtOAc 49:1. $47 \mathrm{mg}$ (0.098 mmol, 98\% yield), white solid (DCM). ${ }^{1} \mathrm{H}$ NMR $\left(400 \mathrm{MHz}, \mathrm{CDCl}_{3}\right) \delta 11.93$ (br t, $\left.J=5.5 \mathrm{~Hz}, 1 \mathrm{H}\right), 8.14-8.07(\mathrm{~m}, 2 \mathrm{H}), 7.57(\mathrm{~s}, 1 \mathrm{H}), 7.55-7.49(\mathrm{~m}, 3 \mathrm{H})$, $7.48-7.38(\mathrm{~m}, 6 \mathrm{H}), 7.37-7.30(\mathrm{~m}, 3 \mathrm{H}), 4.91(\mathrm{~d}, J=5.8 \mathrm{~Hz}, 2 \mathrm{H}), 2.60(\mathrm{~s}, 3 \mathrm{H}) .{ }^{13} \mathrm{C}\left\{{ }^{1} \mathrm{H}\right\} \mathrm{NMR}(101 \mathrm{MHz}$, $\left.\mathrm{CDCl}_{3}\right) \delta 199.8,175.3,164.9,158.3,157.9,153.8,138.2,136.8,136.3,134.5,130.8,129.6,129.2(2 \mathrm{C})$, 128.3 (2C), 128.0, 127.6, 122.2, 113.9, 100.1, 45.5, 32.7. HRMS (ESI/Q-TOF) $\mathrm{m} / z:[\mathrm{M}+\mathrm{H}]^{+}$calcd for $\mathrm{C}_{29} \mathrm{H}_{22} \mathrm{ClN}_{2} \mathrm{O}_{3} 481.1313$, found 481.1308 . 
(S)-Methyl 2-(3-acetyl-5-(4-chlorophenyl)-4-oxo-7-phenyl-4H-pyrano[2,3-b]pyridin-2-ylamino)3-(4-hydroxyphenyl)propanoate (6bb) was prepared from $\mathbf{4 b}$ according to procedure A (2 mL DCM, rt, $120 \mathrm{~h})$ using L-tyrosine methyl ester hydrochloride $(35 \mathrm{mg}, 0.15 \mathrm{mmol})$ and triethylamine $(15 \mu \mathrm{L}, 0.11$ mmol), and was eluted with DCM/EtOAc 8:1. $42 \mathrm{mg}$ (0.074 mmol, 74\% yield), white solid (cyclohexane). $[\alpha]_{\mathrm{D}}^{20}+33.7^{\circ}\left(c\right.$ 0.5, DMSO). ${ }^{1} \mathrm{H}$ NMR $\left(400 \mathrm{MHz}, \mathrm{CDCl}_{3}\right) \delta 11.84(\mathrm{~d}, J=7.8 \mathrm{~Hz}, 1 \mathrm{H}), 8.11-8.04(\mathrm{~m}, 2 \mathrm{H})$, $7.54(\mathrm{~s}, 1 \mathrm{H}), 7.53-7.49(\mathrm{~m}, 3 \mathrm{H}), 7.41(\mathrm{dm}, J=8.5 \mathrm{~Hz}, 2 \mathrm{H}), 7.29(\mathrm{dm}, J=8.5 \mathrm{~Hz}, 2 \mathrm{H}), 7.12(\mathrm{dm}, J=8.5$ $\mathrm{Hz}, 2 \mathrm{H}), 6.74(\mathrm{dm}, J=8.5 \mathrm{~Hz}, 2 \mathrm{H}), 5.49$ (br s, 1H), 5.16 (td, $J=7.8,4.9 \mathrm{~Hz}, 1 \mathrm{H}), 3.82(\mathrm{~s}, 3 \mathrm{H}), 3.32(\mathrm{dd}, J=$ 14.1, $4.9 \mathrm{~Hz}, 1 \mathrm{H}), 3.18(\mathrm{dd}, J=14.1,7.8 \mathrm{~Hz}, 1 \mathrm{H}), 2.58(\mathrm{~s}, 3 \mathrm{H}) .{ }^{1} \mathrm{H}$ NMR (400 MHz, DMSO-d $) \delta 11.55(\mathrm{~d}$, $J=7.3 \mathrm{~Hz}, 1 \mathrm{H}), 9.30(\mathrm{~s}, 1 \mathrm{H}), 8.25-8.19(\mathrm{~m}, 2 \mathrm{H}), 7.83(\mathrm{~s}, 1 \mathrm{H}), 7.59-7.52(\mathrm{~m}, 3 \mathrm{H}), 7.49(\mathrm{dm}, J=8.7 \mathrm{~Hz}$, 2H), $7.44(\mathrm{dm}, J=8.7 \mathrm{~Hz}, 2 \mathrm{H}), 7.06(\mathrm{dm}, J=8.5 \mathrm{~Hz}, 2 \mathrm{H}), 6.68(\mathrm{dm}, J=8.5 \mathrm{~Hz}, 2 \mathrm{H}), 5.13-5.07(\mathrm{~m}, 1 \mathrm{H})$, $3.77(\mathrm{~s}, 3 \mathrm{H}), 3.23(\mathrm{dd}, J=14.1,5.5 \mathrm{~Hz}, 1 \mathrm{H}), 3.17(\mathrm{dd}, J=14.1,6.6 \mathrm{~Hz}, 1 \mathrm{H}), 2.40(\mathrm{~s}, 3 \mathrm{H}) .{ }^{13} \mathrm{C}\left\{{ }^{1} \mathrm{H}\right\} \mathrm{NMR}$ $\left(101 \mathrm{MHz}, \mathrm{DMSO}-d_{6}\right) \delta 197.8,174.6,170.3,163.9,157.1,156.9,156.5,152.8,138.2,136.0,132.7,130.8$, $130.4,130.3$, 129.1, 127.46, 127.42, 125.4, 121.6, 115.3, 113.4, 99.4, 55.6, 52.7, 36.8, 31.9. HRMS (ESI/QTOF) $m / z:[\mathrm{M}+\mathrm{H}]^{+}$calcd for $\mathrm{C}_{32} \mathrm{H}_{26} \mathrm{ClN}_{2} \mathrm{O}_{6} 569.1479$, found 569.1479 .

\section{Ethyl 4-(3-acetyl-5-(4-chlorophenyl)-4-oxo-7-phenyl-4H-pyrano[2,3-b]pyridin-2-}

ylamino)benzoate (6bc) was prepared from $\mathbf{4 b}$ and ethyl 4 -aminobenzoate according to procedure $\mathrm{B}(2 \mathrm{~mL}$ dioxane, $\left.100{ }^{\circ} \mathrm{C}, 36 \mathrm{~h}\right)$. The product was precipitated by addition of dioxane $(2 \mathrm{~mL})$ and cyclohexane $(4$ $\mathrm{mL})$, recovered by filtration, and washed with cyclohexane/dioxane 1:1 and petroleum ether. $33 \mathrm{mg}(0.061$ mmol, $61 \%$ yield), white solid. ${ }^{1} \mathrm{H}$ NMR $\left(400 \mathrm{MHz}, \mathrm{CDCl}_{3}\right) \delta 13.81(\mathrm{~s}, 1 \mathrm{H}), 8.18(\mathrm{dm}, J=8.7 \mathrm{~Hz}, 2 \mathrm{H}), 8.15$ - $8.09(\mathrm{~m}, 2 \mathrm{H}), 7.73(\mathrm{dm}, J=8.7 \mathrm{~Hz}, 2 \mathrm{H}), 7.62(\mathrm{~s}, 1 \mathrm{H}), 7.55-7.50(\mathrm{~m}, 3 \mathrm{H}), 7.45(\mathrm{dm}, J=8.5 \mathrm{~Hz}, 2 \mathrm{H}), 7.34$ $(\mathrm{dm}, J=8.5 \mathrm{~Hz}, 2 \mathrm{H}), 4.42(\mathrm{q}, J=7.1 \mathrm{~Hz}, 2 \mathrm{H}), 2.69(\mathrm{~s}, 3 \mathrm{H}), 1.43(\mathrm{t}, J=7.1 \mathrm{~Hz}, 3 \mathrm{H}) .{ }^{13} \mathrm{C}\left\{{ }^{1} \mathrm{H}\right\} \mathrm{NMR}(101$ $\left.\mathrm{MHz} \mathrm{CDCl}_{3}\right) \delta 200.6,175.5,166.0,162.7,158.7,157.8,153.8,139.7,137.9,136.4,134.7,131.3,131.1$, 129.6, 129.2, 128.4, 128.0, 127.7, 122.3 (2C), 114.0, 100.7, 61.3, 32.9, 14.5. HRMS (ESI/Q-TOF) $m / z:[\mathrm{M}+$ $\mathrm{H}]^{+}$calcd for $\mathrm{C}_{31} \mathrm{H}_{24} \mathrm{ClN}_{2} \mathrm{O}_{5} 539.1368$, found 539.1370.

3-Acetyl-5-(4-bromophenyl)-2-(methylamino)-7-phenyl-4H-pyrano[2,3-b]pyridin-4-one (6ca) was prepared from $4 \mathbf{c}$ and methylamine ( $8.03 \mathrm{M}$ solution in absolute ethanol, $14 \mu \mathrm{L}, 0.11 \mathrm{mmol}$ ) according to procedure A (2 mL DCM, rt, $24 \mathrm{~h}$ ), and was eluted with DCM/EtOAc 24:1. $41 \mathrm{mg}$ (0.091 mmol, 91\% yield), pale yellow solid (cyclohexane). ${ }^{1} \mathrm{H}$ NMR (400 $\left.\mathrm{MHz}, \mathrm{CDCl}_{3}\right) \delta 11.51$ (br q, 1H), $8.13-8.06(\mathrm{~m}$, $2 \mathrm{H}), 7.58(\mathrm{dm}, J=8.5 \mathrm{~Hz}, 2 \mathrm{H}), 7.56(\mathrm{~s}, 1 \mathrm{H}), 7.54-7.47(\mathrm{~m}, 3 \mathrm{H}), 7.26(\mathrm{dm}, J=8.5 \mathrm{~Hz}, 2 \mathrm{H}), 3.31(\mathrm{~d}, J=5.1$ $\mathrm{Hz}, 3 \mathrm{H}), 2.60$ (s, 3H). ${ }^{13} \mathrm{C}\left\{{ }^{1} \mathrm{H}\right\} \mathrm{NMR}\left(101 \mathrm{MHz}, \mathrm{CDCl}_{3}\right) \delta 199.7,175.2,165.8,158.3,158.0,153.8,138.8$, 136.9, 131.2, 130.8, 129.9, 129.2, 127.6, 122.7, 122.1, 113.8, 100.1, 32.7, 28.1. HRMS (ESI/Q-TOF) $\mathrm{m} / z$ : $[\mathrm{M}+\mathrm{H}]^{+}$calcd for $\mathrm{C}_{23} \mathrm{H}_{18}{ }^{79} \mathrm{BrN}_{2} \mathrm{O}_{3} 449.0495$, found 449.0496 ; calcd for $\mathrm{C}_{23} \mathrm{H}_{18}{ }^{81} \mathrm{BrN}_{2} \mathrm{O}_{3} 451.0481$, found 451.0479 . 
and was eluted with DCM/EtOAc 99:1. $47 \mathrm{mg}$ (0.089 mmol, 89\% yield), white solid (cyclohexane). ${ }^{1} \mathrm{H}$ NMR (400 MHz, $\left.\mathrm{CDCl}_{3}\right) \delta 11.93$ (br t, $\left.J=5.6 \mathrm{~Hz}, 1 \mathrm{H}\right), 8.13-8.07(\mathrm{~m}, 2 \mathrm{H}), 7.58(\mathrm{dm}, J=8.5 \mathrm{~Hz}, 2 \mathrm{H}), 7.57$ (s, 1H), $7.54-7.49(\mathrm{~m}, 3 \mathrm{H}), 7.47-7.38(\mathrm{~m}, 4 \mathrm{H}), 7.34(\mathrm{tm}, J=7.1 \mathrm{~Hz}, 1 \mathrm{H}), 7.26(\mathrm{dm}, J=8.5 \mathrm{~Hz}, 2 \mathrm{H}), 4.91$ $(\mathrm{d}, J=5.8 \mathrm{~Hz}, 2 \mathrm{H}), 2.60(\mathrm{~s}, 3 \mathrm{H}) .{ }^{13} \mathrm{C}\left\{{ }^{1} \mathrm{H}\right\} \mathrm{NMR}\left(101 \mathrm{MHz}, \mathrm{CDCl}_{3}\right) \delta 199.8,175.3,164.9,158.3,157.9$, 153.8, 138.8, 136.8, 136.3, 131.2, 130.9, 129.9, 129.2 (2C), 128.3, 128.0, 127.6, 122.7, 122.1, 113.9, 100.0, 45.5, 32.7. HRMS (ESI/Q-TOF) $m / z$ : $[\mathrm{M}+\mathrm{H}]^{+}$calcd for $\mathrm{C}_{29} \mathrm{H}_{22}{ }^{79} \mathrm{BrN}_{2} \mathrm{O}_{3} 525.0808$, found 525.0821 ; calcd for $\mathrm{C}_{29} \mathrm{H}_{22}{ }^{81} \mathrm{BrN}_{2} \mathrm{O}_{3} 527.0794$, found 527.0806.

\section{Ethyl 4-(3-acetyl-5-(4-bromophenyl)-4-oxo-7-phenyl-4H-pyrano[2,3-b]pyridin-2-}

ylamino)benzoate (6cc) was prepared from $4 \mathbf{c}$ and ethyl 4-aminobenzoate according to procedure B $(2 \mathrm{~mL}$ dioxane, $\left.100{ }^{\circ} \mathrm{C}, 36 \mathrm{~h}\right)$. The product was precipitated by addition of dioxane $(2 \mathrm{~mL})$ and cyclohexane $(4$ $\mathrm{mL})$, recovered by filtration, and washed with cyclohexane/dioxane 1:1 and petroleum ether. $39 \mathrm{mg}(0.067$ mmol, 67\% yield), pale yellow solid. ${ }^{1} \mathrm{H}$ NMR $\left(400 \mathrm{MHz}, \mathrm{CDCl}_{3}\right) \delta 13.81(\mathrm{~s}, 1 \mathrm{H}), 8.18(\mathrm{dm}, J=8.7 \mathrm{~Hz}$, 2H), $8.15-8.09(\mathrm{~m}, 2 \mathrm{H}), 7.73(\mathrm{dm}, J=8.7 \mathrm{~Hz}, 2 \mathrm{H}), 7.62(\mathrm{~s}, 1 \mathrm{H}), 7.60(\mathrm{dm}, J=8.4 \mathrm{~Hz}, 2 \mathrm{H}), 7.56-7.50(\mathrm{~m}$, $3 \mathrm{H}), 7.28(\mathrm{dm}, J=8.4 \mathrm{~Hz}, 2 \mathrm{H}), 4.42(\mathrm{q}, J=7.1 \mathrm{~Hz}, 2 \mathrm{H}), 2.69(\mathrm{~s}, 3 \mathrm{H}), 1.43(\mathrm{t}, J=7.1 \mathrm{~Hz}, 3 \mathrm{H}) .{ }^{13} \mathrm{C}\left\{{ }^{1} \mathrm{H}\right\}$ NMR (101 MHz, $\left.\mathrm{CDCl}_{3}\right) \delta 200.6,175.5,166.0,162.7,158.7,157.8,153.8,139.7,138.4,136.4,131.3$ (2C), $131.1,129.9,129.2,128.0,127.7,122.9,122.32$, 122.26, 113.9, 100.6, 61.3, 32.9, 14.5. HRMS (ESI/QTOF) $m / z:[\mathrm{M}+\mathrm{H}]^{+}$calcd for $\mathrm{C}_{31} \mathrm{H}_{24}{ }^{79} \mathrm{BrN}_{2} \mathrm{O}_{5} 583.0863$, found 583.0854 ; calcd for $\mathrm{C}_{31} \mathrm{H}_{24}{ }^{81} \mathrm{BrN}_{2} \mathrm{O}_{5}$ 585.0848 , found 585.0841 .

\section{3-Acetyl-5-(4-t-butoxyphenyl)-2-(methylamino)-7-phenyl-4H-pyrano[2,3-b]pyridin-4-one (6da)} was prepared from $4 \mathbf{d}$ and methylamine ( $8.03 \mathrm{M}$ solution in absolute ethanol, $14 \mu \mathrm{L}, 0.11 \mathrm{mmol}$ ) according to procedure A (1 mL DCM, rt, $12 \mathrm{~h}$ ), and was eluted with DCM/EtOAc 9:1. $42 \mathrm{mg}$ (0.095 mmol, 95\% yield), white solid (cyclohexane). ${ }^{1} \mathrm{H}$ NMR (400 MHz, $\left.\mathrm{CDCl}_{3}\right) \delta 11.46$ (br q, $\left.J=4.9 \mathrm{~Hz}, 1 \mathrm{H}\right), 8.14-8.07$ $(\mathrm{m}, 2 \mathrm{H}), 7.61(\mathrm{~s}, 1 \mathrm{H}), 7.54-7.45(\mathrm{~m}, 3 \mathrm{H}), 7.31(\mathrm{dm}, J=8.6 \mathrm{~Hz}, 2 \mathrm{H}), 7.05(\mathrm{dm}, J=8.6 \mathrm{~Hz}, 2 \mathrm{H}), 3.30(\mathrm{~d}, J$ $=5.1 \mathrm{~Hz}, 3 \mathrm{H}), 2.61(\mathrm{~s}, 3 \mathrm{H}), 1.44(\mathrm{~s}, 9 \mathrm{H}) .{ }^{13} \mathrm{C}\left\{{ }^{1} \mathrm{H}\right\} \mathrm{NMR}\left(101 \mathrm{MHz}, \mathrm{CDCl}_{3}\right) \delta 199.7,175.4,165.7,158.1$, 157.9, 156.0, 155.0, 137.1, 134.2, 130.6, 129.2, 129.1, 127.6, 122.9, 122.5, 113.9, 100.2, 78.9, 32.5, 29.1, 28.0. HRMS (ESI/Q-TOF) $m / z:[\mathrm{M}+\mathrm{H}]^{+}$calcd for $\mathrm{C}_{27} \mathrm{H}_{27} \mathrm{~N}_{2} \mathrm{O}_{4} 443.1965$, found 443.1960 .

\section{Ethyl 4-(3-acetyl-5-(4-t-butoxyphenyl)-4-oxo-7-phenyl-4H-pyrano[2,3-b]pyridin-2-}

ylamino)benzoate (6db) was prepared from $4 \mathbf{d}$ and ethyl 4-aminobenzoate according to procedure B $(2 \mathrm{~mL}$ dioxane, $\left.100{ }^{\circ} \mathrm{C}, 36 \mathrm{~h}\right)$. The product was precipitated by addition of dioxane $(2 \mathrm{~mL})$ and cyclohexane $(8$ $\mathrm{mL})$, recovered by filtration, and washed with cyclohexane/dioxane 2:1 and petroleum ether. $22 \mathrm{mg}(0.038$ mmol, $38 \%$ yield), white solid. ${ }^{1} \mathrm{H}$ NMR $\left(400 \mathrm{MHz} \mathrm{CDCl}_{3}\right) \delta 13.77(\mathrm{~s}, 1 \mathrm{H}), 8.18(\mathrm{dm}, J=8.7 \mathrm{~Hz}, 2 \mathrm{H}), 8.16$ $-8.11(\mathrm{~m}, 2 \mathrm{H}), 7.73(\mathrm{dm}, J=8.7 \mathrm{~Hz}, 2 \mathrm{H}), 7.67(\mathrm{~s}, 1 \mathrm{H}), 7.56-7.49(\mathrm{~m}, 3 \mathrm{H}), 7.33(\mathrm{dm}, J=8.6 \mathrm{~Hz}, 2 \mathrm{H}), 7.08$ $(\mathrm{dm}, J=8.6 \mathrm{~Hz}, 2 \mathrm{H}), 4.41(\mathrm{q}, J=7.1 \mathrm{~Hz}, 2 \mathrm{H}), 2.69(\mathrm{~s}, 3 \mathrm{H}), 1.45(\mathrm{~s}, 9 \mathrm{H}), 1.43(\mathrm{t}, J=7.1 \mathrm{~Hz}, 3 \mathrm{H}) .{ }^{13} \mathrm{C}\left\{{ }^{1} \mathrm{H}\right\}$ NMR $\left(101 \mathrm{MHz}, \mathrm{CDCl}_{3}\right) \delta 200.7,175.7,166.0,162.6,158.3,157.9,156.1,155.0,139.8,136.7,133.8$, 
131.2, 130.9, 129.3, 129.1, 127.8, 127.7, 123.0, 122.6, 122.2, 114.0, 100.7, 78.9, 61.3, 32.7, 29.1, 14.5. HRMS (ESI/Q-TOF) $m / z:[\mathrm{M}+\mathrm{H}]^{+}$calcd for $\mathrm{C}_{35} \mathrm{H}_{33} \mathrm{~N}_{2} \mathrm{O}_{6}$ 577.2333, found 577.2342.

\section{3-Acetyl-2-(benzylamino)-5-(4-morpholinophenyl)-7-phenyl-4H-pyrano[2,3-b]pyridin-4-one}

(6ea) was prepared from $4 \mathbf{e}$ and benzylamine $(12 \mu \mathrm{L}, 0.11 \mathrm{mmol})$ according to procedure A ( $2 \mathrm{~mL} \mathrm{DCM}, \mathrm{rt}$, $24 \mathrm{~h})$, and was eluted with DCM/EtOAc 9:1. $43 \mathrm{mg}(0.081 \mathrm{mmol}, 81 \%$ yield), bright yellow solid (cyclohexane). ${ }^{1} \mathrm{H}$ NMR (400 MHz, $\left.\mathrm{CDCl}_{3}\right) \delta 11.87(\mathrm{t}, J=5.7 \mathrm{~Hz}, 1 \mathrm{H}), 8.12-8.07(\mathrm{~m}, 2 \mathrm{H}), 7.61(\mathrm{~s}, 1 \mathrm{H})$, $7.55-7.31(\mathrm{~m}, 10 \mathrm{H}), 6.97(\mathrm{dm}, J=8.8 \mathrm{~Hz}, 2 \mathrm{H}), 4.91(\mathrm{~d}, J=5.8 \mathrm{~Hz}, 2 \mathrm{H}), 3.92-3.85(\mathrm{~m}, 4 \mathrm{H}), 3.31-3.24$ $(\mathrm{m}, 4 \mathrm{H}), 2.63(\mathrm{~s}, 3 \mathrm{H}) .{ }^{13} \mathrm{C}\left\{{ }^{1} \mathrm{H}\right\} \mathrm{NMR}\left(101 \mathrm{MHz}, \mathrm{CDCl}_{3}\right) \delta 199.8,175.7,164.8,158.1,157.8,154.9,151.2$, 137.1 , 136.3, 130.6, 130.3, 129.8, 129.14, 129.10, 128.2, 127.9, 127.5, 122.4, 114.4, 113.7, 100.1, 67.0, 48.6, 45.4, 32.7. HRMS (ESI/Q-TOF) $\mathrm{m} / z$ : $[\mathrm{M}+\mathrm{H}]^{+}$calcd for $\mathrm{C}_{33} \mathrm{H}_{30} \mathrm{~N}_{3} \mathrm{O}_{4}$ 532.2231, found 532.2229.

\section{3-Acetyl-5-(4-morpholinophenyl)-7-phenyl-2-(phenylamino)-4H-pyrano[2,3-b]pyridin-4-one}

(6eb) was prepared from $4 \mathbf{e}$ and aniline according to procedure $\mathrm{B}\left(2 \mathrm{~mL}\right.$ dioxane, $\left.85^{\circ} \mathrm{C}, 12 \mathrm{~h}\right)$. The product was precipitated by addition of dioxane $(2 \mathrm{~mL})$ and cyclohexane $(8 \mathrm{~mL})$, recovered by filtration, and washed with cyclohexane/dioxane 2:1 and petroleum ether. $46 \mathrm{mg}\left(0.089 \mathrm{mmol}, 89 \%\right.$ yield), yellowish solid. ${ }^{1} \mathrm{H}$ NMR (400 MHz, $\left.\mathrm{CDCl}_{3}\right) \delta 13.58(\mathrm{~s}, 1 \mathrm{H}), 8.13-8.08(\mathrm{~m}, 2 \mathrm{H}), 7.64(\mathrm{~s}, 1 \mathrm{H}), 7.65-7.61(\mathrm{~m}, 2 \mathrm{H}), 7.53-7.47$ $(\mathrm{m}, 5 \mathrm{H}), 7.38(\mathrm{dm}, J=8.8 \mathrm{~Hz}, 2 \mathrm{H}), 7.31(\mathrm{tm}, J=7.4 \mathrm{~Hz}, 1 \mathrm{H}), 6.98(\mathrm{dm}, J=8.8 \mathrm{~Hz}, 2 \mathrm{H}), 3.93-3.86(\mathrm{~m}$, $4 \mathrm{H}), 3.32-3.26(\mathrm{~m}, 4 \mathrm{H}), 2.71(\mathrm{~s}, 3 \mathrm{H}) .{ }^{13} \mathrm{C}\left\{{ }^{1} \mathrm{H}\right\} \mathrm{NMR}\left(101 \mathrm{MHz}, \mathrm{CDCl}_{3}\right) \delta 200.3,175.9,162.7,158.2$, $158.1,154.9,151.3,137.0,135.7,130.7,130.1,129.9$, 129.7, 129.1, 127.6, 126.4, 123.2, 122.4, 114.4, 113.9, 100.4, 67.0, 48.7, 32.8. HRMS (ESI/Q-TOF) $m / z:[\mathrm{M}+\mathrm{H}]^{+}$calcd for $\mathrm{C}_{32} \mathrm{H}_{28} \mathrm{~N}_{3} \mathrm{O}_{4}$ 518.2074, found 518.2074.

General procedure for the formation of open-ring products 7a-b (Scheme 6). 2-(Methylthio)-8azachromone $4 \mathbf{a}(39 \mathrm{mg}, 0.1 \mathrm{mmol})$ and secondary cyclic amine $(0.3 \mathrm{mmol})$ were dissolved in anhydrous DCM $(1 \mathrm{~mL})$ under argon atmosphere, and the resulting mixture was stirred under the indicated conditions. After completion, the reaction mixture was diluted with an excess volume of DCM, washed with $\mathrm{H}_{2} \mathrm{O}(3 \mathrm{x})$ and brine, then dried over $\mathrm{Na}_{2} \mathrm{SO}_{4}$ and concentrated. The product was isolated by flash chromatography on silica gel and then precipitated by addition of the indicated solvent. Note: safety precautions must be taken due to the release of toxic methanethiol.

\section{3-(2-(Di(piperidin-1-yl)methylene)-1,3-dioxobutyl)-4,6-diphenyl-2(1H)-pyridone}

(7a) was prepared from 4a and piperidine according to the general procedure ( $\mathrm{rt}, 36 \mathrm{~h}$ ), and was isolated by flash chromatography (DCM/MeOH 9:1). $50 \mathrm{mg}$ (0.098 mmol, 98\%), yellowish solid (hexane). ${ }^{1} \mathrm{H}$ NMR (400 $\left.\mathrm{MHz}, \mathrm{CDCl}_{3}\right) \delta 11.76$ (br s, 1H), $7.74-7.67(\mathrm{~m}, 2 \mathrm{H}), 7.59-7.53(\mathrm{~m}, 2 \mathrm{H}), 7.49-7.38(\mathrm{~m}, 3 \mathrm{H}), 7.35-7.27$ $(\mathrm{m}, 3 \mathrm{H}), 6.52(\mathrm{~s}, 1 \mathrm{H}), 3.43$ (br s, 4H), 3.01 (br s, 4H), $2.02(\mathrm{~s}, 3 \mathrm{H}), 1.78-1.28(\mathrm{~m}, 12 \mathrm{H}) .{ }^{13} \mathrm{C}\left\{{ }^{1} \mathrm{H}\right\} \mathrm{NMR}$ $\left(151 \mathrm{MHz} \mathrm{CDCl}_{3}\right) \delta 190.7,184.7,173.9,163.0,149.2,144.6,139.4,133.7,133.2,129.9,129.3,128.6$, 128.2 (2C), 126.6, 109.8, 107.6, 51.7 (br, 2C), 28.5, 25.5 (2C), 24.33, 24.28. HRMS (ESI/Q-TOF) $m / z:$ [M $\mathrm{H}]^{-}$calcd for $\mathrm{C}_{32} \mathrm{H}_{34} \mathrm{~N}_{3} \mathrm{O}_{3} 508.2600$, found 508.2599. 
3-(2-(Dimorpholinomethylene)-1,3-dioxobutyl)-4,6-diphenyl-2(1H)-pyridone (7b) was prepared from $4 \mathbf{a}$ and morpholine according to the general procedure ( $\mathrm{rt}, 60 \mathrm{~h}$ ), and was isolated by flash chromatography (DCM/MeOH 9:1). $37 \mathrm{mg}$ (0.072 mmol, 72\%), yellowish solid (hexane). ${ }^{1} \mathrm{H}$ NMR (400 $\left.\mathrm{MHz}, \mathrm{CDCl}_{3}\right) \delta 11.86($ br s, $1 \mathrm{H}), 7.73-7.64(\mathrm{~m}, 2 \mathrm{H}), 7.58-7.51(\mathrm{~m}, 2 \mathrm{H}), 7.51-7.42(\mathrm{~m}, 3 \mathrm{H}), 7.38-7.28$ $(\mathrm{m}, 3 \mathrm{H}), 6.52(\mathrm{~s}, 1 \mathrm{H}), 4.09-2.82(\mathrm{~m}, 16 \mathrm{H}), 2.09(\mathrm{~s}, 3 \mathrm{H}) .{ }^{13} \mathrm{C}\left\{{ }^{1} \mathrm{H}\right\} \mathrm{NMR}\left(101 \mathrm{MHz}, \mathrm{CDCl}_{3}\right) \delta 190.5,184.6$, 173.6, 162.9, 149.7, 145.2, 139.2, 133.6, 132.4, 130.2, 129.4, 128.5 (2C), 128.4, 126.7, 108.9, 107.7, 65.8 (2C), 51.2 (br, 2C), 28.4. HRMS (ESI/Q-TOF) $m / z:[\mathrm{M}+\mathrm{H}]^{+}$calcd for $\mathrm{C}_{30} \mathrm{H}_{32} \mathrm{~N}_{3} \mathrm{O}_{5} 514.2336$, found 514.2330 .

General procedure for the synthesis of 2-(substituted amino)-8-azachromones 6an-ap, 6bd, 6cd, 6dc and 6ec (Scheme 8). 2-(Methylthio)-8-azachromone 4 (0.1 mmol), amine (0.15 mmol) and KOt-Bu (12 $\mathrm{mg}, 0.11 \mathrm{mmol})$ were dissolved in anhydrous THF $(2 \mathrm{~mL})$ under argon atmosphere, and the resulting mixture was stirred $12 \mathrm{~h}$ at rt. After completion, an excess volume of DCM was added and the medium was neutralized with saturated aq $\mathrm{NH}_{4} \mathrm{Cl}$. The organic layer was separated and the aqueous layer was extracted again with DCM. The combined organic layers were washed with saturated aq $\mathrm{NH}_{4} \mathrm{Cl}(4 \mathrm{x})$, dried over $\mathrm{Na}_{2} \mathrm{SO}_{4}$ and concentrated. The product was isolated by flash chromatography on silica gel and then precipitated by addition of the indicated solvent. Note: safety precautions must be taken due to the release of toxic methanethiol.

\section{Methyl 5-(3-acetyl-4-oxo-5,7-diphenyl-4H-pyrano[2,3-b]pyridin-2-ylamino)pyridine-2-}

carboxylate (6an) was prepared from $4 \mathbf{a}$ and methyl 5 -aminopicolinate according to the general procedure, and was isolated by flash chromatography (DCM/MeOH 99:1). $20 \mathrm{mg}(0.041 \mathrm{mmol}, 41 \%$ yield), white solid (cyclohexane). ${ }^{1} \mathrm{H}$ NMR (400 MHz, $\left.\mathrm{CDCl}_{3}\right) \delta 13.98(\mathrm{~s}, 1 \mathrm{H}), 9.09(\mathrm{~d}, J=2.6 \mathrm{~Hz}, 1 \mathrm{H}), 8.30(\mathrm{~d}, J=8.6 \mathrm{~Hz}$, $1 \mathrm{H}), 8.20(\mathrm{dd}, J=8.6,2.6 \mathrm{~Hz}, 1 \mathrm{H}), 8.17-8.11(\mathrm{~m}, 2 \mathrm{H}), 7.69(\mathrm{~s}, 1 \mathrm{H}), 7.56-7.44(\mathrm{~m}, 6 \mathrm{H}), 7.43-7.36(\mathrm{~m}$, 2H), $4.06(\mathrm{~s}, 3 \mathrm{H}), 2.70(\mathrm{~s}, 3 \mathrm{H}) .{ }^{13} \mathrm{C}\left\{{ }^{1} \mathrm{H}\right\} \mathrm{NMR}\left(101 \mathrm{MHz}, \mathrm{CDCl}_{3}\right) \delta 201.1,175.4,165.2,163.0,158.7,157.7$, $155.3,144.4,143.5,139.3,136.4,136.0,131.2$, 129.6, 129.2, 128.6, 128.2, 128.1, 127.7, 126.2, 122.6, 114.1, 101.1, 53.2, 32.7. HRMS (ESI/Q-TOF) $\mathrm{m} / \mathrm{z}:[\mathrm{M}+\mathrm{H}]^{+}$calcd for $\mathrm{C}_{29} \mathrm{H}_{22} \mathrm{~N}_{3} \mathrm{O}_{5} 492.1559$, found 492.1560.

\section{Ethyl}

\section{5-(3-acetyl-4-oxo-5,7-diphenyl-4H-pyrano[2,3-b]pyridin-2-ylamino)pyridine-2-}

carboxylate (6ao) was prepared from 4a and ethyl 5-aminopicolinate according to the general procedure, and was isolated by flash chromatography (DCM/MeOH 99:1). $24 \mathrm{mg}(0.047 \mathrm{mmol}, 47 \%$ yield), white solid (cyclohexane). ${ }^{1} \mathrm{H} \mathrm{NMR}\left(400 \mathrm{MHz}, \mathrm{CDCl}_{3}\right) \delta 13.97$ (s, 1H), 9.09 (d, $\left.J=2.6 \mathrm{~Hz}, 1 \mathrm{H}\right), 8.30$ (d, $J=8.6 \mathrm{~Hz}$, $1 \mathrm{H}), 8.19$ (dd, $J=8.6,2.6 \mathrm{~Hz}, 1 \mathrm{H}), 8.17-8.11(\mathrm{~m}, 2 \mathrm{H}), 7.69(\mathrm{~s}, 1 \mathrm{H}), 7.55-7.46(\mathrm{~m}, 6 \mathrm{H}), 7.43-7.36$ (m, $2 \mathrm{H}), 4.53(\mathrm{q}, J=7.1 \mathrm{~Hz}, 2 \mathrm{H}), 2.70(\mathrm{~s}, 3 \mathrm{H}), 1.48(\mathrm{t}, J=7.1 \mathrm{~Hz}, 3 \mathrm{H}) .{ }^{13} \mathrm{C}\left\{{ }^{1} \mathrm{H}\right\} \mathrm{NMR}\left(101 \mathrm{MHz}, \mathrm{CDCl}_{3}\right) \delta$ 201.1, 175.4, 164.7, 163.0, 158.7, 157.7, 155.3, 144.8, 143.6, 139.3, 136.4, 135.9, 131.1, 129.6, 129.2, 128.6, 128.2, 128.1, 127.7, 126.2, 122.7, 114.1, 101.1, 62.3, 32.7, 14.5. HRMS (ESI/Q-TOF) $m / z:[\mathrm{M}+\mathrm{H}]^{+}$ calcd for $\mathrm{C}_{30} \mathrm{H}_{24} \mathrm{~N}_{3} \mathrm{O}_{5} 506.1716$, found 506.1719. 
3-Acetyl-2-(isoxazol-3-ylamino)-5,7-diphenyl-4H-pyrano[2,3-b]pyridin-4-one (6ap) was prepared from 4a and 3-aminoisoxazole according to the general procedure, and was isolated by flash chromatography (DCM/EtOAc 99:1). $16 \mathrm{mg}$ (0.038 mmol, 38\% yield), pale yellow solid (cyclohexane). ${ }^{1} \mathrm{H}$ $\operatorname{NMR}\left(400 \mathrm{MHz}, \mathrm{CDCl}_{3}\right) \delta 13.90(\mathrm{~s}, 1 \mathrm{H}), 8.50(\mathrm{~d}, J=1.7 \mathrm{~Hz}, 1 \mathrm{H}), 8.18-8.11(\mathrm{~m}, 2 \mathrm{H}), 7.70(\mathrm{~s}, 1 \mathrm{H}), 7.55-$ $7.47(\mathrm{~m}, 6 \mathrm{H}), 7.43-7.38(\mathrm{~m}, 2 \mathrm{H}), 7.24(\mathrm{~d}, J=1.7 \mathrm{~Hz}, 1 \mathrm{H}), 2.67(\mathrm{~s}, 3 \mathrm{H}) .{ }^{13} \mathrm{C}\left\{{ }^{1} \mathrm{H}\right\} \mathrm{NMR}\left(126 \mathrm{MHz}, \mathrm{CDCl}_{3}\right)$ $\delta 200.6,175.4,162.2$, 160.1, 158.6, 157.9, 156.0, 155.4, 139.2, 136.5, 131.1, 129.2, 128.6, 128.20, 128.14, 127.7, 122.7, 114.1, 101.1, 100.8, 32.8. HRMS (ESI/Q-TOF) $m / z:[\mathrm{M}+\mathrm{H}]^{+}$calcd for $\mathrm{C}_{25} \mathrm{H}_{18} \mathrm{~N}_{3} \mathrm{O}_{4} 424.1297$, found 424.1298 .

\section{Ethyl} 5-(3-acetyl-5-(4-chlorophenyl)-4-oxo-7-phenyl-4H-pyrano[2,3-b]pyridin-2-

ylamino)pyridine-2-carboxylate (6bd) was prepared from $\mathbf{4 b}$ and ethyl 5-aminopicolinate according to the general procedure, and was isolated by flash chromatography (DCM/MeOH 99:1). $25 \mathrm{mg}$ (0.046 mmol, 46\% yield), pale yellow solid (cyclohexane). ${ }^{1} \mathrm{H}$ NMR (500 MHz, $\left.\mathrm{CDCl}_{3}\right) \delta 13.98(\mathrm{~s}, 1 \mathrm{H}), 9.09$ (d, $J=2.4 \mathrm{~Hz}$, $1 \mathrm{H}), 8.30(\mathrm{~d}, J=8.5 \mathrm{~Hz}, 1 \mathrm{H}), 8.17(\mathrm{dd}, J=8.5,2.6 \mathrm{~Hz}, 1 \mathrm{H}), 8.15-8.10(\mathrm{~m}, 2 \mathrm{H}), 7.64(\mathrm{~s}, 1 \mathrm{H}), 7.55-7.50$ $(\mathrm{m}, 3 \mathrm{H}), 7.45(\mathrm{dm}, J=8.5 \mathrm{~Hz}, 2 \mathrm{H}), 7.33(\mathrm{dm}, J=8.5 \mathrm{~Hz}, 2 \mathrm{H}), 4.52(\mathrm{q}, J=7.1 \mathrm{~Hz}, 2 \mathrm{H}), 2.70(\mathrm{~s}, 3 \mathrm{H}), 1.48(\mathrm{t}$, $J=7.1 \mathrm{~Hz}, 3 \mathrm{H}) .{ }^{13} \mathrm{C}\left\{{ }^{1} \mathrm{H}\right\} \mathrm{NMR}\left(126 \mathrm{MHz}, \mathrm{CDCl}_{3}\right) \delta 201.0,175.3,164.7,162.9,158.9,157.7,154.0,144.9$, 143.6, 137.6, 136.1, 135.7, 134.7, 131.3, 129.67, 129.62, 129.2, 128.4, 127.7, 126.2, 122.5, 113.9, 101.0, 62.3, 32.8, 14.5. HRMS (ESI/Q-TOF) $m / z:[\mathrm{M}+\mathrm{H}]^{+}$calcd for $\mathrm{C}_{30} \mathrm{H}_{23} \mathrm{ClN}_{3} \mathrm{O}_{5} 540.1321$, found 540.1314.

Ethyl 5-(3-acetyl-5-(4-bromophenyl)-4-oxo-7-phenyl-4H-pyrano[2,3-b]pyridin-2ylamino)pyridine-2-carboxylate $(\mathbf{6 c d})$ was prepared from $\mathbf{4 c}$ and ethyl 5-aminopicolinate according to the general procedure, and was isolated by flash chromatography (DCM/MeOH 99:1). $28 \mathrm{mg}$ (0.048 mmol, 48\% yield), pale yellow solid (cyclohexane). ${ }^{1} \mathrm{H} \mathrm{NMR}\left(400 \mathrm{MHz}, \mathrm{CDCl}_{3}\right) \delta 13.99(\mathrm{~s}, 1 \mathrm{H}), 9.10(\mathrm{~d}, J=2.5 \mathrm{~Hz}$, $1 \mathrm{H}), 8.30(\mathrm{~d}, J=8.5 \mathrm{~Hz}, 1 \mathrm{H}), 8.18(\mathrm{dd}, J=8.6,2.6 \mathrm{~Hz}, 1 \mathrm{H}), 8.16-8.10(\mathrm{~m}, 2 \mathrm{H}), 7.64(\mathrm{~s}, 1 \mathrm{H}), 7.61(\mathrm{dm}, J=$ $8.4 \mathrm{~Hz}, 2 \mathrm{H}), 7.56-7.50(\mathrm{~m}, 3 \mathrm{H}), 7.28(\mathrm{dm}, J=8.4 \mathrm{~Hz}, 2 \mathrm{H}), 4.53(\mathrm{q}, J=7.1 \mathrm{~Hz}, 2 \mathrm{H}), 2.70(\mathrm{~s}, 3 \mathrm{H}), 1.48(\mathrm{t}, J$ $=7.1 \mathrm{~Hz}, 3 \mathrm{H}) .{ }^{13} \mathrm{C}\left\{{ }^{1} \mathrm{H}\right\} \mathrm{NMR}\left(101 \mathrm{MHz}, \mathrm{CDCl}_{3}\right) \delta 201.0,175.3,164.7,163.0,159.0,157.7,154.0,144.9$, 143.6, 138.2, 136.2, 135.7, 131.33, 131.30, 129.9, 129.7, 129.2, 127.7, 126.2, 123.0, 122.4, 113.9, 101.0, 62.3, 32.8, 14.5. HRMS (ESI/Q-TOF) $m / z:[\mathrm{M}+\mathrm{H}]^{+}$calcd for $\mathrm{C}_{30} \mathrm{H}_{23}{ }^{79} \mathrm{BrN}_{3} \mathrm{O}_{5}$ 584.0816, found 584.0800 ; calcd for $\mathrm{C}_{30} \mathrm{H}_{23}{ }^{81} \mathrm{BrN}_{3} \mathrm{O}_{5} 586.0801$, found 586.0781.

\section{Methyl}

\section{5-(3-acetyl-5-(4-t-butoxyphenyl)-4-oxo-7-phenyl-4H-pyrano[2,3-b]pyridin-2-}

ylamino)pyridine-2-carboxylate (6dc) was prepared from $\mathbf{4 d}$ and methyl 5-aminopicolinate according to the general procedure, and was isolated by flash chromatography (DCM/MeOH 99:1). $28 \mathrm{mg}(0.049 \mathrm{mmol}$, $49 \%$ yield), white solid (cyclohexane). ${ }^{1} \mathrm{H}$ NMR (400 MHz, $\left.\mathrm{CDCl}_{3}\right) \delta 13.95(\mathrm{~s}, 1 \mathrm{H}), 9.08(\mathrm{~d}, J=2.4 \mathrm{~Hz}$, $1 \mathrm{H}), 8.30(\mathrm{~d}, J=8.6 \mathrm{~Hz}, 1 \mathrm{H}), 8.20(\mathrm{dd}, J=8.6,2.6 \mathrm{~Hz}, 1 \mathrm{H}), 8.17-8.11(\mathrm{~m}, 2 \mathrm{H}), 7.69(\mathrm{~s}, 1 \mathrm{H}), 7.56-7.48$ (m, 3H), $7.32(\mathrm{dm}, J=8.6 \mathrm{~Hz}, 2 \mathrm{H}), 7.08(\mathrm{dm}, J=8.6 \mathrm{~Hz}, 2 \mathrm{H}), 4.05(\mathrm{~s}, 3 \mathrm{H}), 2.71(\mathrm{~s}, 3 \mathrm{H}), 1.45$ (s, 9H). ${ }^{13} \mathrm{C}\left\{{ }^{1} \mathrm{H}\right\} \mathrm{NMR}\left(101 \mathrm{MHz}, \mathrm{CDCl}_{3}\right) \delta 201.1,175.5,165.2,162.9,158.5,157.9,156.3,155.2,144.4,143.5$, 
136.5, 136.0, 133.5, 131.1, 129.6, 129.3, 129.2, 127.7, 126.2, 123.0, 122.7, 114.0, 101.2, 79.0, 53.2, 32.6, 29.1. HRMS (ESI/Q-TOF) $m / z:[\mathrm{M}+\mathrm{H}]^{+}$calcd for $\mathrm{C}_{33} \mathrm{H}_{30} \mathrm{~N}_{3} \mathrm{O}_{6}$ 564.2129, found 564.2133.

\section{Methyl 5-(3-acetyl-5-(4-morpholinophenyl)-4-oxo-7-phenyl-4H-pyrano[2,3-b]pyridin-2-}

ylamino)pyridine-2-carboxylate (6ec) was prepared from $4 \mathbf{e}$ and methyl 5-aminopicolinate according to the general procedure, and was isolated by flash chromatography (DCM/MeOH 198:2 then 197:3). $21 \mathrm{mg}$ (0.036 mmol, 36\% yield), yellowish solid (cyclohexane). ${ }^{1} \mathrm{H}$ NMR (500 MHz, $\left.\mathrm{CDCl}_{3}\right) \delta 13.95(\mathrm{~s}, 1 \mathrm{H}), 9.07$ $(\mathrm{d}, J=2.3 \mathrm{~Hz}, 1 \mathrm{H}), 8.30(\mathrm{~d}, J=8.6 \mathrm{~Hz}, 1 \mathrm{H}), 8.21(\mathrm{dd}, J=8.6,2.6 \mathrm{~Hz}, 1 \mathrm{H}), 8.16-8.10(\mathrm{~m}, 2 \mathrm{H}), 7.68$ (s, $1 \mathrm{H}), 7.55-7.50(\mathrm{~m}, 3 \mathrm{H}), 7.37(\mathrm{dm}, J=8.8 \mathrm{~Hz}, 2 \mathrm{H}), 6.98(\mathrm{dm}, J=8.8 \mathrm{~Hz}, 2 \mathrm{H}), 4.05(\mathrm{~s}, 3 \mathrm{H}), 3.93-3.85(\mathrm{~m}$, $4 \mathrm{H}), 3.33-3.25(\mathrm{~m}, 4 \mathrm{H}), 2.72(\mathrm{~s}, 3 \mathrm{H}) .{ }^{13} \mathrm{C}\left\{{ }^{1} \mathrm{H}\right\} \mathrm{NMR}\left(126 \mathrm{MHz}, \mathrm{CDCl}_{3}\right) \delta$ 201.1, 175.7, 165.2, 162.8, 158.4 , 158.0, 155.2, 151.4, 144.3, 143.4, 136.5, 136.0, 131.0, 129.9, 129.7, 129.5, 129.2, 127.6, 126.3, 122.6, 114.4, 113.8, 101.2, 67.0, 53.2, 48.6, 32.8. HRMS (ESI/Q-TOF) $m / z:[\mathrm{M}+\mathrm{H}]^{+}$calcd for $\mathrm{C}_{33} \mathrm{H}_{29} \mathrm{~N}_{4} \mathrm{O}_{6}$ 577.2082, found 577.2087.

\section{ASSOCIATED CONTENT}

Supporting Information. Copies of ${ }^{1} \mathrm{H}$ and ${ }^{13} \mathrm{C}$ NMR spectra of all new compounds described in the experimental section, copies of ${ }^{1} \mathrm{H}$ NMR spectra of 4-bromochalcone and compound $\mathbf{2 a}$.

\section{AUTHOR INFORMATION}

*Corresponding author, email: jean-pierre.uttaro@umontpellier.fr

\section{ACKNOWLEDGMENTS}

This work was supported by institutional funds from the Institut National du Cancer (INCa 11560) and the University of Montpellier (R.G. PhD fellowship). The authors appreciate the contribution of C. Hennebert (Master student).

\section{REFERENCES}

\footnotetext{
${ }^{1}$ Bonsall, C.; Hill, J. 8-Azachromones. J. Chem. Soc. C 1967, 1836-1839.

${ }^{2}$ For a recent review on the synthesis of azachromones, see: Malets, Y. S.; Moskvina, V. S.; Grygorenko, O. O.; Brovarets, V. S. Synthesis of azachromones and azachromanones. Chem. Heterocycl. Compd. 2019, 55, $1007-1012$.

${ }^{3}$ (a) Gaspar, A.; Matos, M. J.; Garrido, J.; Uriarte, E.; Borges, F. Chromone: A Valid Scaffold in Medicinal Chemistry. Chem. Rev. 2014, 114, 4960-4992. (b) Horton, D. A.; Bourne, G. T.; Smythe, M. L. The
} 
Combinatorial Synthesis of Bicyclic Privileged Structures or Privileged Substructures. Chem. Rev. 2003, 103, 893-930.

${ }^{4}$ (a) Safrygin, A. V.; Barabanov, M. A.; Irgashev, R. A.; Sosnovskikh, V. Ya. Synthesis and reactivity of 8aza-5,7-dimethyl-2-trifluoroacetylchromone. Chem. Heterocycl. Compd. 2015, 51, 838-844. (b) Sosnovskikh, V. Ya.; Barabanov, M. A. The first synthesis of 8-aza-2-polyfluoroalkylchromones. $J$. Fluorine Chem. 2003, 120, 25-28. (c) Moffet, R. B. Azacoumarins. J. Org. Chem. 1970, 35, 3596-3600.

${ }^{5}$ (a) Khlebnikov, V.; Patel, K.; Zhou, X.; Reddy, M. M.; Su, Z.; Chiacchia, F. S.; Hansen, H. C. Synthesis of 2-aryl-4H-pyrano[2,3-b]pyridin-4-ones by a one-pot deprotection-cyclization reaction. Tetrahedron 2009, 65, 6932 - 6940. (b) Sarges, R.; Goldstein, S. W.; Welch, W. M.; Swindell, A. C.; Siegel, T. W.; Beyer, T. A. Spiro hydantoin aldose reductase inhibitors derived from 8-aza-4-chromanones. J. Med. Chem. 1990, 33, $1859-1865$.

${ }^{6}$ Zhao, J.; Zhao, Y.; Fu, H. Transition-Metal-Free Intramolecular Ullmann-Type O-Arylation: Synthesis of Chromone Derivatives. Angew. Chem., Int. Ed. 2011, 50, 3769-3773.

${ }^{7}$ Wang, D.; Feng, H.; Li, L.; Liu, Z.; Yan, Z.; Yu, P. Access to 8-Azachromones via Activation of C-H in N-Oxides. J. Org. Chem. 2017, 82, 11275-11287.

${ }^{8}$ Eiden, F.; Rademacher, G. Mono-, di- and triazaxanthones from azachromones. Arch. Pharm. (Weinheim) 1985, 318, 926-931.

${ }^{9}$ (a) Mayr, H. Reactivity scales for quantifying polar organic reactivity: the benzhydrylium methodology. Tetrahedron 2015, 71, 5095-5111. (b) Mayr, H.; Ofial, A. R. Do general nucleophilicity scales exist? J. Phys. Org. Chem. 2008, 21, 584-595. (c) Mayr, H.; Kempf, B.; Ofial, A. R. $\pi$-Nucleophilicity in Carbon-Carbon Bond-Forming Reactions. Acc. Chem. Res. 2003, 36, 66-77. (d) Mayr, H.; Patz, M. Scales of Nucleophilicity and Electrophilicity: A System for Ordering Polar Organic and Organometallic Reactions. Angew. Chem., Int. Ed. Engl. 1994, 33, 938-957.

${ }^{10}$ Jain, R.; Roschangar, F.; Ciufolini, M. A. A one-step preparation of functionalized 3-cyano-2-pyridones. Tetrahedron Lett. 1995, 36, 3307-3310.

11 Carles, L.; Narkunan, K.; Penlou, S.; Rousset, L.; Bouchu, D.; Ciufolini, M. A. 2-Pyridones from Cyanoacetamides and Enecarbonyl Compounds: Application to the Synthesis of Nothapodytine B. J. Org. Chem. 2002, 67, 4304-4308.

12 (a) Shringare, S. N.; Chavan, H. V.; Bhale, P. S.; Dongare, S. B.; Mule, Y. B.; Patil, S. P.; Bandgar, B. P. Synthesis and pharmacological evaluation of combretastatin-A4 analogs of pyrazoline and pyridine derivatives as anticancer, anti-inflammatory and antioxidant agents. Med. Chem. Res. 2018, 27, 12261237. (b) Abdel Motaal, E. A.; El-Gaby, M. S. A.; Salem, M. A. Design, synthesis and anticancer activity of new 3-cyano-2-(1H)-pyridone and 3-cyanopyridine-2-(1H)-thione Derivatives. Orient. J. Chem. 2015, 31, 875-884. (c) El-Shehawy, A. A.; Attia, A. M. E. Michael Addition of Activated Nitriles to 4[(+)-Camphor10'-Sulfonylamino]acetophenone and Some of its Chalcones. Phosphorus, Sulfur Silicon Relat Elem. 2003, 
178, 1129-1142. (d) Soto, J. L.; Seoane, C.; Mansilla, A. M. A simple one-step synthesis of 2-pyridones from benzylidenacetophenones. Org. Prep. Proced. Int. 1981, 13, 331-336.

${ }^{13}$ Kuntz, K. W.; Campbell, J. E.; Keilhack, H.; Pollock, R. M.; Knutson, S. K.; Porter-Scott, M.; Richon, V. M.; Sneeringer, C. J.; Wigle, T. J.; Allain, C. J.; Majer, C. R.; Moyer, M. P.; Copeland, R. A.; Chesworth, R. The Importance of Being Me: Magic Methyls, Methyltransferase Inhibitors, and the Discovery of Tazemetostat. J. Med. Chem. 2016, 59, 1556-1564.

14 (a) Langer, J.; Krieck, S.; Fischer, R.; Görls, H.; Walther, D.; Westerhausen, M. 1,4-Dioxane Adducts of Grignard Reagents: Synthesis, Ether Fragmentation Reactions, and Structural Diversity of Grignard Reagent/1,4-Dioxane Complexes. Organometallics 2009, 28, 5814-5820. (b) Handbook of Grignard Reagents; Silverman, G. S., Rakita, P. E., Eds.; Dekker: New York, 1996.

15 (a) Eiden, F.; Rademacher, G. Synthese und Reaktionen von 3-Acyl-2-methylthio-chromonen. Arch. Pharm. (Weinheim) 1983, 316, 34-42. (b) Eiden, F.; Schweiger, H.-D. 11H,12H-[1]Benzopyrano[2,3-b] benzopyran-11,12-dione. Synthesis 1974, 1974, 511-513.

16 Databases are available from https://www.cup.lmu.de/oc/mayr/reaktionsdatenbank/ and https://www.cup.lmu.de/oc/mayr/reaktionsdatenbank2/.

${ }^{17}$ Sosnovskikh, V. Ya.; Barabanov, M. A.; Usachev, B. I. Reactions of 5,7-dimethyl-2-polyfluoroalkyl-8azachromones with N-nucleophiles. Russ. Chem. Bull. 2003, 52, 1758-1767.

${ }^{18}$ Brotzel, F.; Mayr, H. Nucleophilicities of amino acids and peptides. Org. Biomol. Chem. 2007, 5, 38143820.

${ }^{19}$ Bordwell, F. G. Equilibrium acidities in dimethyl sulfoxide solution. Acc. Chem. Res. 1988, 21, 456-463.

${ }^{20}$ Breugst, M.; Corral Bautista, F.; Mayr, H. Nucleophilic Reactivities of the Anions of Nucleobases and Their Subunits. Chem. Eur. J. 2012, 18, 127-137.

21 (a) Shi, H.; Nagai, J.; Sakatsume, T.; Bandow, K.; Okudaira, N.; Sakagami, H.; Tomomura, M.; Tomomura, A.; Uesawa, Y.; Takao, K.; Sugita, Y. Quantitative Structure-Cytotoxicity Relationship of 2-(Ncyclicamino)chromone Derivatives. Anticancer Res. 2018, 38, 3897-3906. (b) Sakagami, H.; Okudaira, N.; Uesawa, Y.; Takao, K.; Kagaya, H.; Sugita, Y. Quantitative Structure-Cytotoxicity Relationship of 2Azolylchromones. Anticancer Res. 2018, 38, 763-770. (c) Samanta, R.; Narayan, R.; Bauer, J. O.; Strohmann, C.; Sievers, S.; Antonchick, A. P. Oxidative regioselective amination of chromones exposes potent inhibitors of the hedgehog signaling pathway. Chem. Commun. 2015, 51, 925-928. (d) Hatnapure, G. D.; Keche, A. P.; Rodge, A. H.; Birajdar, S. S.; Tale, R. H.; Kamble, V. M. Synthesis and biological evaluation of novel piperazine derivatives of flavone as potent anti-inflammatory and antimicrobial agent. Bioorg. Med. Chem. Lett. 2012, 22, 6385-6390. (e) Mazzei, M.; Sottofattori, E.; Dondero, R.; Ibrahim, M.; Melloni, E.; Michetti, M. N,N-Dialkylaminosubstituted chromones and isoxazoles as potential antiinflammatory agents. Farmaco 1999, 54, 452-460.

22 (a) Pawluć, P.; Szudkowska, J.; Hreczycho, G.; Marciniec, B. One-Pot Synthesis of (E)-Styryl Ketones from Styrenes. J. Org. Chem. 2011, 76, 6438-6441. (b) Stroba, A.; Schaeffer, F.; Hindie, V.; Lopez- 
Garcia, L.; Adrian, I.; Fröhner, W.; Hartmann, R. W.; Biondi, R. M.; Engel, M. 3,5-Diphenylpent-2-enoic Acids as Allosteric Activators of the Protein Kinase PDK1: Structure-Activity Relationships and Thermodynamic Characterization of Binding as Paradigms for PIF-Binding Pocket-Targeting Compounds. J. Med. Chem. 2009, 52, 4683-4693. (c) Moulton, B. E.; Duhme-Klair, A. K.; Fairlamb, I. J. S.; Lynam, J. M.; Whitwood, A. C. A Rationale for the Linear Correlation of Aryl Substituent Effects in Iron(0) Tricarbonyl Complexes Containing $\alpha, \beta$-Unsaturated Enone (Chalcone) Ligands. Organometallics 2007, 26, 6354-6365. (d) Gorman, A.; Killoran, J.; O’Shea, C; Kenna, T.; Gallagher, W. M.; O’Shea, D. F. In Vitro Demonstration of the Heavy-Atom Effect for Photodynamic Therapy. J. Am. Chem. Soc. 2004, 126, 10619-10631.

${ }^{23}$ Rai, S. K.; Khanam, S.; Khanna, R. S.; Tewari, A. K. Cascade synthesis of 2-pyridones using acrylamides and ketones. RSC Adv. 2014, 4, 44141—44145.

24 (a) Al-Neyadi, S. S.; Hassan, A. H.; Abdou, I. M. Microwave-Assisted Synthesis of 2(1H)-Pyridones and Their Glucosides as Cell Proliferation Inhibitors. Nucleosides Nucleotides Nucleic Acids 2011, 30, 120134. (b) Alberola, A.; Andrés, C.; González Ortega, A.; Pedrosa, R.; Vicente, M. The reaction of $\beta$-aminoenones with substituted acetonitriles. Regiospecific synthesis of $2(1 \mathrm{H})$-pyridones. J. Heterocycl. Chem. 1987, 24, 709-713.

25 (a) Rong, L.; Han, H.; Jiang, H.; Shi, D.; Tu, S. One-Pot Synthesis of 4,6-Diaryl-2-oxo-1,2-dihydropyridine-3-carbonitriles via Three-Component Cyclocondensation under Solvent-Free Conditions. Synth. Commun. 2008, 38, 217-224. (b) Rong, L.; Wang, H.; Shi, J.; Yang, F.; Yao, H.; Tu, S.; Shi, D. An efficient and facile procedure for the synthesis of 4,6-diaryl-2(1H)-pyridones under solvent-free conditions. J. Heterocyclic Chem. 2007, 44, 1505-1508.

${ }^{26} \mathrm{Li}, \mathrm{W}$.; Chen, Y.; Lam, Y. A facile solid-phase synthesis of 3,4,6-trisubstituted-2-pyridones using sodium benzenesulfinate as a traceless linker. Tetrahedron Lett. 2004, 45, 6545-6547.

${ }^{27}$ Tohda, Y.; Yanagidani, T.; Hiramatsu, S.; Nishiwaki, N.; Tani, K.; Imagawa, K.; Ariga, M. Synthesis via 2-Acylmethyl-2-oxazoline. I. A Novel Synthesis of 3-Acyl-2-pyridones by Michael Addition of 2Acylmethyl-2-oxazoline to $\alpha, \beta$-Acetylenic Ketones. Bull. Chem. Soc. Jpn. 1997, 70, 2781-2790. 